\title{
Secondary Metabolites in the Green Synthesis of Metallic Nanoparticles
}

\author{
Gregory Marslin 1,+ (D), Karthik Siram 2,+ , Qaisar Maqbool ${ }^{3}$ (D), \\ Rajendran Kamalabai Selvakesavan ${ }^{3}$, Dariusz Kruszka ${ }^{3}$, Piotr Kachlicki ${ }^{3}$ (D) and \\ Gregory Franklin 3,* (iD) \\ 1 Ratnam Institute of Pharmacy and Research, Nellore 524346, India; marslingregory@gmail.com \\ 2 Department of Pharmaceutics, PSG College of Pharmacy, Coimbatore 641004, India; \\ karthiksiram@gmail.com \\ 3 Institute of Plant Genetics of the Polish Academy of Sciences, Poznan 60479, Poland; \\ Qaisar.vu@gmail.com (Q.M.); kesavanrks@gmail.com (R.K.S.); dmkruszka@gmail.com (D.K.); \\ pkac@igr.poznan.pl (P.K.); fgre@igr.poznan.pl (G.F.) \\ * Correspondence: fgre@igr.poznan.pl; Tel.: +48-616-550-266 \\ + Equal contribution.
}

Received: 29 April 2018; Accepted: 30 May 2018; Published: 3 June 2018

\begin{abstract}
The ability of organisms and organic compounds to reduce metal ions and stabilize them into nanoparticles (NPs) forms the basis of green synthesis. To date, synthesis of NPs from various metal ions using a diverse array of plant extracts has been reported. However, a clear understanding of the mechanism of green synthesis of NPs is lacking. Although most studies have neglected to analyze the green-synthesized NPs (GNPs) for the presence of compounds derived from the extract, several studies have demonstrated the conjugation of sugars, secondary metabolites, and proteins in these biogenic NPs. Despite several reports on the bioactivities (antimicrobial, antioxidant, cytotoxic, catalytic, etc.) of GNPs, only a handful of studies have compared these activities with their chemically synthesized counterparts. These comparisons have demonstrated that GNPs possess better bioactivities than NPs synthesized by other methods, which might be attributed to the presence of plant-derived compounds in these NPs. The ability of NPs to bind with organic compounds to form a stable complex has huge potential in the harvesting of precious molecules and for drug discovery, if harnessed meticulously. A thorough understanding of the mechanisms of green synthesis and high-throughput screening of stabilizing/capping agents on the physico-chemical properties of GNPs is warranted to realize the full potential of green nanotechnology.
\end{abstract}

Keywords: nanoparticles; green synthesis; secondary metabolites; flavonoids; bioactivities; nano-harvesting; drug discovery

\section{Introduction}

Nanoparticles (NPs) are particles that range 1-100 nm in size. Owing to the large surface area to volume ratio, NPs exhibit enhanced catalytic reactivity, biological activities, thermal conductivity, non-linear optical performance, and chemical steadiness in comparison to their bulk form. As a result of these properties, NPs are used in health, food, feed, space, chemical, cosmetic industries, and in agriculture [1-3]. NPs can be synthesized by several methods, including physical and chemical processes (Figure 1). However, as a result of the difficulties in scaling-up the physical processes and the usage of toxic synthetic chemicals that could be carried over by the NPs in chemical processes, alternative methods, such as green synthesis, have been developed. Although green chemistry methods 
have been practiced in agriculture, consumer products, and medicines for many years, the application of green chemistry to synthesize nanoparticles (NPs) is relatively recent.

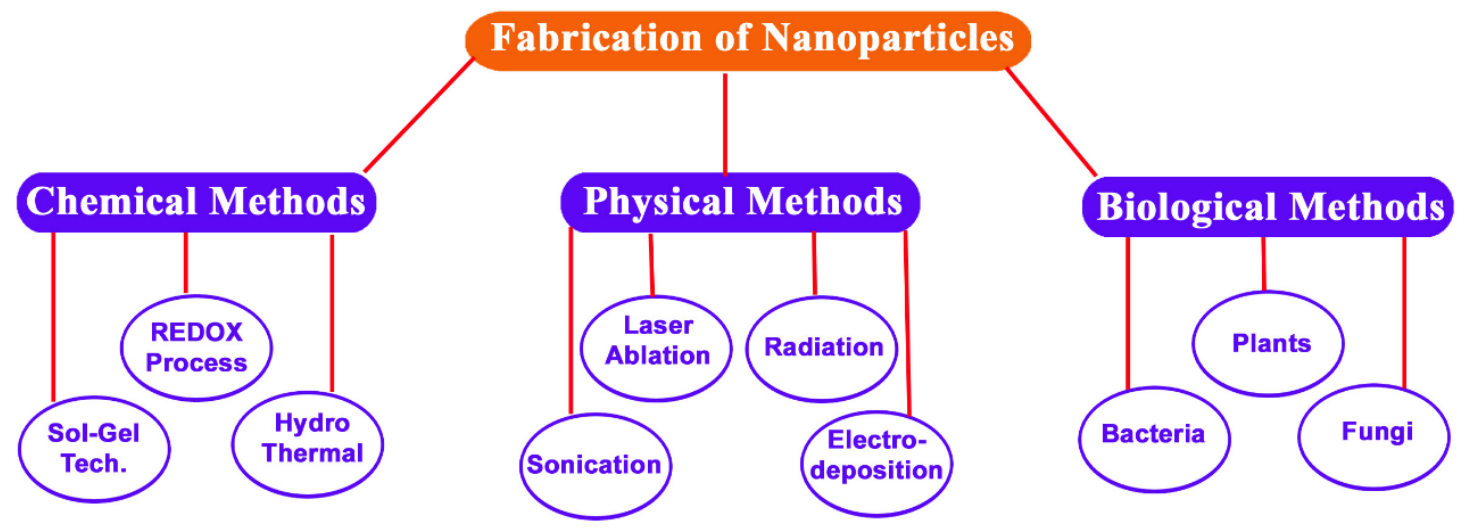

Figure 1. Schematic presentation of various methods used in the synthesis of metal NPs.

Green synthesis is based on redox reaction, in which metal ions are reduced to stable NPs by the components of an organism or its extract. Although living organisms, such as algae, fungi, bacteria and plants, could synthesize NPs in vivo [4-12], plant extract-mediated, in vitro green synthesis of NPs has gained popularity due to its simplicity, low cost, eco-friendly nature, and easiness to scale-up $[13,14]$. Although plant extract-mediated green synthesis is a recent technology, a contrasting process has been used for the preparation of Bhasma (ash of metal) in Ayurveda, a traditional Indian medicine practiced for more than 2000 years. In the former, metal ions are reduced and stabilized as NPs by the components of the extract (bottom-up approach); by contrast, in the latter, NPs are produced by the calcination of metal sheets (top-down approach), which are macerated with medicinal plant extracts to obtain therapeutic potential.

Currently, the number of reports on green-synthesized nanoparticles (GNPs) is increasing exponentially. Extracts derived from diverse plant species, their organs, and isolated compounds are being successfully used in the green synthesis of NPs. In addition to being eco-friendly, NPs can be synthesized using agricultural and industrial waste to make the process more sustainable $[15,16]$. GNPs often possess better bioactivities [17-20] and catalytic characteristics compared to their counterparts, which are synthesized by other methods [21,22]; this is probably a result of the compounds attached to their surface [14]. The ability of plant secondary metabolites to bind or conjugate with NPs upon green synthesis could be exploited for the purification of compounds and drug discovery. Although the widespread occurrence of phenolic compounds in the plant kingdom could explain the ability of plant extracts to reduce metal ions, the mechanism of green synthesis is not fully understood. In this article, the current status and potential applications of the green synthesis of NPs with special emphasize on secondary metabolites participating in this process are discussed.

\section{Mechanism of Green Synthesis of NPs by Plants}

A process known as bioaccumulation, which provides plants with the ability to detoxify metal ions, can explain the mechanism of NP synthesis by plants. When plants absorb metal ions at a rate faster than that of their removal by catabolism, the excess metal ions accumulate in the plant tissues. The presence of metals at toxic levels can induce excessive reactive oxygen species (ROS) production in the cells and damage cellular macromolecules resulting in serious morphological, metabolic, and physiological irregularities in plants. To counteract the metal toxicity, plants are equipped with sophisticated chelation mechanisms to detoxify metals [23]. Cysteine-rich oligopeptides, phytochelatins, and low molecular weight proteins named metallothioneins can form complexes with metals and eventually remove the metal ions via vacuolar sequestration [24]. 
To maintain the ROS homeostasis upon metal toxicity, cellular enzymatic antioxidant systems are activated [25]. In addition to the enzymatic antioxidant mechanisms, plant secondary metabolites, such as phenolic compounds, can assist the cells in the maintenance of ROS homeostasis [26,27]. Induction of plant secondary metabolism in response to metal stress has been frequently reported. Stimulation of key enzymes of the phenylpropanoid pathway, such as phenylalanine ammonia-lyase (PAL) and chalcone synthase (CHS), has been observed in plants upon exposure to $\mathrm{Cu}, \mathrm{Cd}, \mathrm{Al}, \mathrm{Pb}$, and Ni [28]. Pteris vittata, a hyperaccumulator, produces high concentrations of chlorogenic acid derivatives and a-type procyanidin upon $\mathrm{Cu}$ stress [29]. Similarly, elevation of phenolic content in maize exposed to Al [30] and Phaseolus vulgaris exposed to $\mathrm{Cu}$ [31] has been reported. The enhanced biosynthesis of phenolic compounds by the plants under metal stress might be due to the high tendency of these compounds to chelate metals [32]. Several flavonoids are capable of chelating metal ions by forming stable complex through their multiple hydroxyl $(-\mathrm{OH})$ groups and the carbonyl moiety. For instance, quercetin, a flavonoid that possesses three potential bidentate binding sites, namely $\alpha$-hydroxy-carbonyl, $\beta$-hydroxy-carbonyl or catechol having two -OH groups in ortho positions, can form stable complex with metal cations such as Mo(VI), Fe(II)/Fe(III), Cu(II), Zn(II), Al(III), Tb(III), $\mathrm{Pb}$ (II), $\mathrm{Co}(\mathrm{II})$ by quercetin has also been reported [33].

When serving as antioxidants in a concentration-dependent manner to scavenge ROS, phenolic compounds are toxic to the cell due to their high chemical reactivity and protein-denaturing properties [34]. Hence, plants transfer these compounds to compartments with lower biosynthetic activity, such as the extracellular space and the vacuole. Flavonoids are synthesized in the cytosol and transported into the vacuole for storage [35]. The multidrug and toxic efflux transporter TT12, which is localized in the vacuolar membrane, mediates flavonoid transport by an H+-antiport mechanism into the vacuole [36]. Thus, the accumulation of metal ions and antioxidant phenolic compounds in the same cellular compartment might facilitate the formation of NPs (Figure 2).

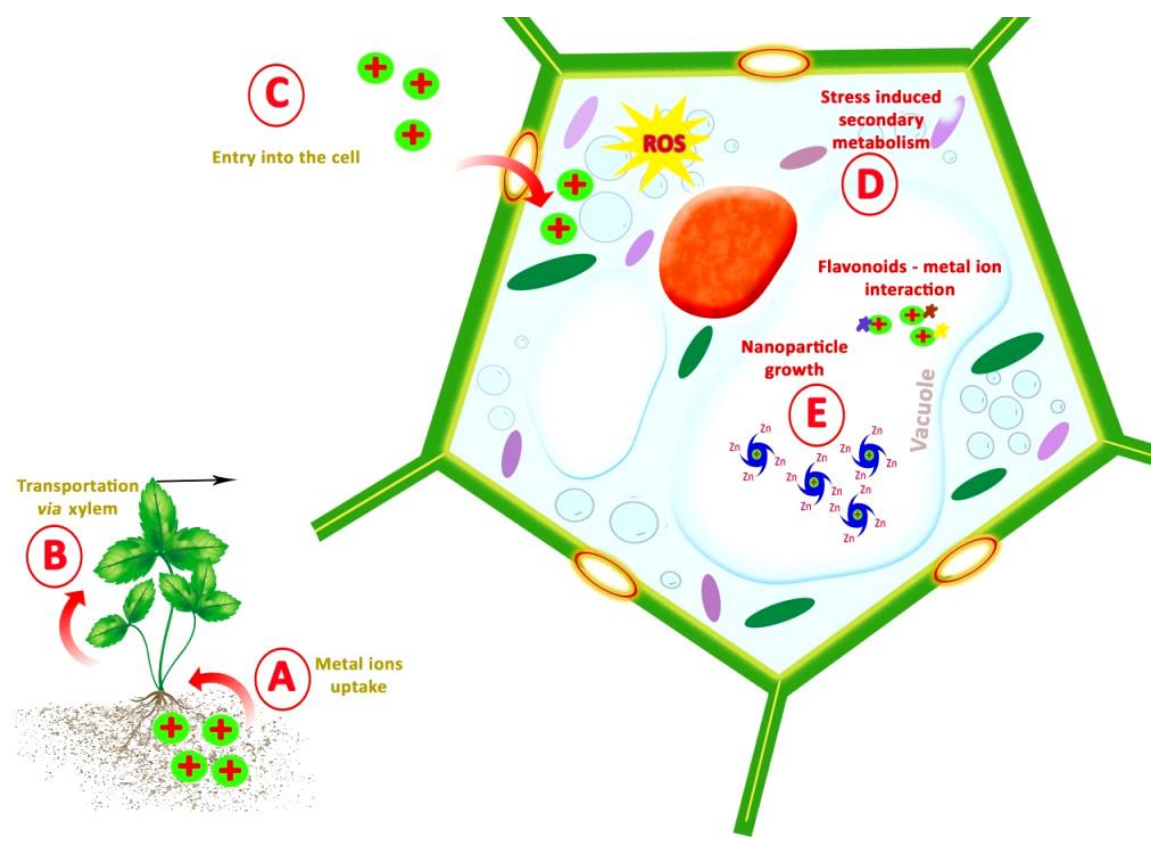

Figure 2. A scheme describing the possible mechanism of in vivo green synthesis of NPs.

Many plant species have the ability to synthesize and store NPs in their cells. For example, Medicago sativa (alfalfa) plants grown on an $\mathrm{AuCl}_{4}$ rich environment accumulated $4 \mathrm{~nm}$ size Au NPs in their tissues [7]. Similarly, when grown on an Ag ion rich medium, M. sativa accumulated Ag NPs [8]. M. sativa plants could accumulate Ag NPs of $50 \mathrm{~nm}$ size to about $13.6 \%$ of their fresh weight when grown on a solution containing $\mathrm{AgNO}_{3}$ [9]. Under the same conditions, Brassica juncea accumulated 
similar NPs to about $12.4 \%$ of fresh weight [9]. The uptake of $\mathrm{AgNO}_{3}$, sodium dithiosulfatoargentate $\left[\mathrm{Na}_{3} \mathrm{Ag}\left(\mathrm{S}_{2} \mathrm{O}_{3}\right)_{2}\right]$, and diamine silver nitrate $\left[\mathrm{Ag}\left(\mathrm{NH}_{3}\right)_{2} \mathrm{NO}_{3}\right]$ by hydroponically grown $B$. juncea and the conversion of these salts to silver metal NPs has been quantified [10]. Brassica napus, which was cultured on medium containing $\mathrm{AgNO}_{3}$, accumulated $\mathrm{Ag} \mathrm{NPs}$ in the regenerated leaves [11]. Spatial distribution of Ag NPs in the chloroplast, cytoplasmic spaces, vacuolar, and nucleolar regions was confirmed by transmission electron microscopic analysis of tissues obtained from Vigna radiata plants exposed to $\mathrm{AgNO}_{3}$ [12]. Interestingly, the ability of Phragmites australis and Iris pseudacorus to transform Cu ions into $\mathrm{Cu}$ NPs in and around their roots has been revealed when grown in $\mathrm{Cu}$-contaminated soil in the natural environment [37].

\section{Mechanism of Green Synthesis of NPs by Plant Extracts}

A similar mechanism as discussed above could be operating during green synthesis of NPs by plant extracts in vitro. Figure 3 schematically describes the formation of metallic NPs from the corresponding metal ions. When metallic salt dissociates into cation and anion, cations will be saturated to form hydroxyl complexes. Immediately after the supersaturation of hydroxyl complexes, crystillite growth of metal with oxygen species starts to originate. This results in the formation of crystalline planes with different energy levels. Heat plays a key role in providing energy to the reaction system. The process continues until activation of the capping agent from the plant extracts, which will ultimately arrest the growth of high-energy atomic growth planes. This results in the formation of specific type NPs. Generally, during the synthesis, the reducing agents donate electrons to the metal ions and convert them to NPs. These NPs exist at a high-surface energy state and tend to convert to their low-surface energy conformations by aggregating against each other. Thus, the presence of higher amounts of reducing agents and stabilizing agents prevents the aggregation of nanoparticles and promotes production of smaller NPs. Additionally, proteins can trap metal ions on their surface and convert them to their corresponding nuclei, which could further aggregate and, consequently, form NPs [38]. Amine groups of proteins, hydroxyl and carboxyl groups of polyphenols and amino acids, hydroxyl groups of polysaccharides, and carboxyl groups of organic acids chelate metal ions and suppress the superoxide-driven Fenton reaction (which is believed to be the most important source of ROS), catalyzing the formation of metallic NPs.

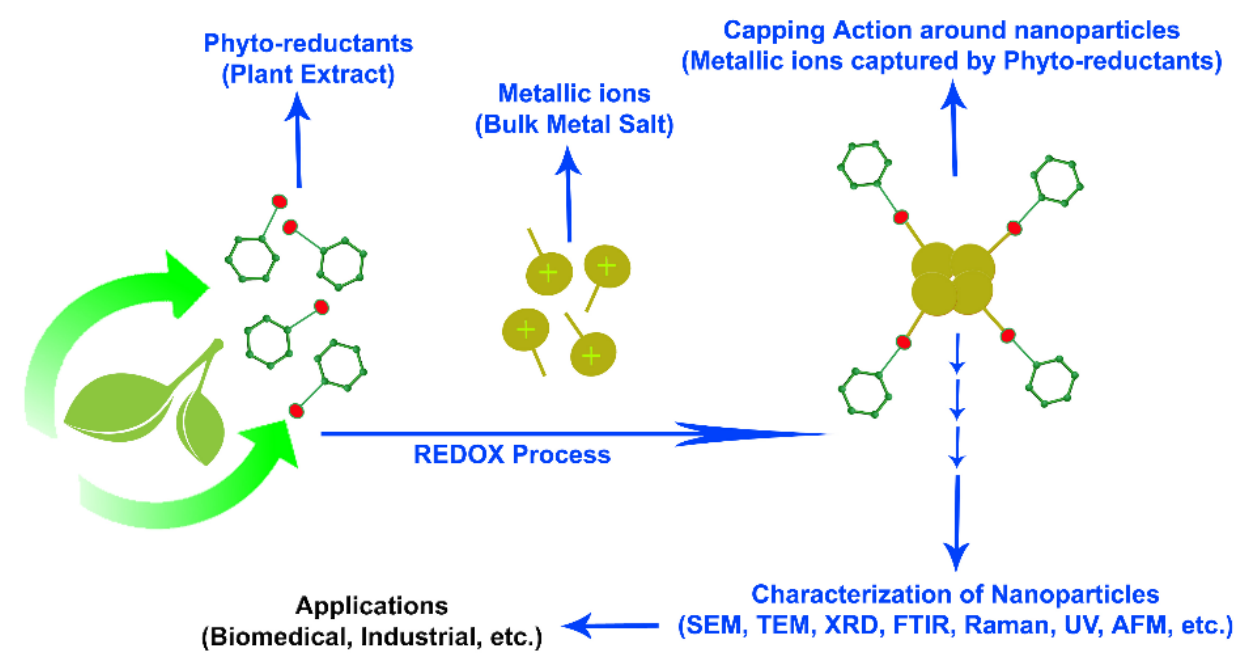

Figure 3. A scheme describing the mechanism of in vitro green synthesis of nanoparticles.

Although it is essential to form a protein-metal ion complex for the vacuolar sequestration of metal ions during in vivo accumulation of NPs, the role of proteins upon in vitro green synthesis is not clear. Interestingly, plant extracts possess the capacity to reduce metal ions and produce NPs even after boiling [39-42]. Although boiling could denature proteins by altering their secondary and tertiary 
structures, the peptide bonds of the primary structure between the amino acids are left intact. Because all structural levels of the protein determine its function, the denatured protein can no longer be fully functional. It has been stated that the protein can bind to Au NPs, either through free amino groups or cysteine residues; the surface-bound protein lead to the stabilization of the NPs [43].

\section{Secondary Metabolites in Plant Extract-Mediated Green Synthesis of NPs}

Synthesis of NPs using plant extracts has been reported in several plant species (Table 1). A wide range of molecules, ranging from proteins to various low molecular weight compounds such as terpenoids, alkaloids, amino acids, alcoholic compounds, polyphenols (catechin, flavones, taxifolin, procyanidins of various chain lengths formed by catechin and epicatechin units, and phenolic acids), glutathiones, polysaccharides, antioxidants, organic acids (ascorbic, oxalic, malic, tartaric, and protocatechuic acid), quinones etc., have been reported to play a role in the green synthesis of NPs. The participation of sugars, terpenoids, polyphenols, alkaloids, phenolic acids, and proteins in the reduction of metal ions into NPs and in supporting their subsequent stability has also been postulated [38]. As seen in Table 1, flavonoids have been the compounds most commonly reported/ predicted to participate in the green synthesis.

Table 1. Plant components possibly involved in the green synthesis of nanoparticles from various plant species.

\begin{tabular}{|c|c|c|c|}
\hline Plant Species & NPs & Metabolites Identified in the Extract/NPs & Reference \\
\hline Coleus aromaticus & $\mathrm{Ag}$ & Flavonoids & [44] \\
\hline Syzygium cumini & $\mathrm{Ag}$ & Flavonoids & [45] \\
\hline Azadirachta indica & $\mathrm{Ag}$ & Flavanoids, terpenoids & [46] \\
\hline Citrus sinensis & $\mathrm{Ag}$ & Flavonoids, ascorbic acid, volatile oils & [47] \\
\hline Zingiber officinale & $\mathrm{Ag}$ & Flavonoid, alkaloids & [48] \\
\hline Ocimum sanctum & $\mathrm{Ag}$ & Eugenols, linalool, terpenes & [49] \\
\hline Glycyrrhiza glabra & $\mathrm{Ag}$ & Flavonoids, thiamine and terpenoids & {$[50]$} \\
\hline Nigella arvensis & $\mathrm{Ag}$ & Flavonoids, alkaloids & {$[51]$} \\
\hline Dioscorea bulbifera & $\mathrm{Ag}$ & Flavonoids, polyphenols & {$[52]$} \\
\hline Lantana camara & $\mathrm{Ag}$ & Flavonoids, glycosides and carbohydrates & {$[53]$} \\
\hline Helianthus annuus & $\mathrm{Ag}$ & Fatty acids, triglycerides, phenolics, tocopherols & [54] \\
\hline Rosmarinus officinalis & $\mathrm{Ag}$ & Polyphenols & [55] \\
\hline Mimusops elengi & $\mathrm{Ag}$ & Polyphenols & [56] \\
\hline Syzygium cumini & $\mathrm{Ag}$ & Polyphenols & [57] \\
\hline Ocimum sanctum & $\mathrm{Ag}$ & Quercetin & [58] \\
\hline Acalypha indica & $\mathrm{Ag}$ & Quercetin, plant pigment & [59] \\
\hline Gardenia jasminoides & $\mathrm{Ag}$ & Rutin, gallic acid, chlorogenic acid & [60] \\
\hline Withania somnifera & $\mathrm{Ag}$ & Catechin p-coumaric acid, luteolin-7-glucoside, withanolides & {$[14]$} \\
\hline Lippia citriodora & $\mathrm{Ag}$ & Verbascoside, isoverbascoside, chrysoeriol-7-O-diglucoronide, & [61] \\
\hline Decalepis hamiltonii & $\mathrm{Ag}$ & Polyols, phenols & [62] \\
\hline Achyranthes aspera & $\mathrm{Ag}$ & Polyols & [63] \\
\hline Hybanthus enneaspermus & $\mathrm{Ag}$ & Several bioactive phytochemical compounds & [64] \\
\hline Desmodium triflorum & $\mathrm{Ag}$ & Ascorbic acid & [65] \\
\hline Sesuvium portulacastrum & $\mathrm{Ag}$ & Flavones, proteins, terpenoids & [66] \\
\hline Solanum xanthocarpum & $\mathrm{Ag}$ & Alcohols, phenols, carboxylic anions & [67] \\
\hline Mentha piperita & $\mathrm{Ag}$ & $\begin{array}{l}\text { Alkaloids, flavones, steroids, polysaccharides, amino acids, } \\
\text { oximes, proteins, menthol }\end{array}$ & [41] \\
\hline Anacardium occidentale & $\mathrm{Ag}$ & Proteins, polyols & [68] \\
\hline Dioscorea bulbifera & $\mathrm{Ag}$ & Diosgenin, ascorbic acid & [52] \\
\hline Iresine herbstii & $\mathrm{Ag}$ & Phenolic compound & [69] \\
\hline Trianthema decandra & $\mathrm{Ag}$ & Catechins, hydroxyflavones & [70] \\
\hline Morinda pubescens & $\mathrm{Ag}$ & Flavonoids, triterpenoids, polyphenols & [71] \\
\hline Carica papaya & $\mathrm{Ag}$ & Proteins, alcohols, phenolics & [72] \\
\hline Annona squamosa & $\mathrm{Ag}$ & $\begin{array}{l}\text { Alkaloids, glycoside, saponins, tannins, } \\
\text { phenolic, carbohydrates }\end{array}$ & [73] \\
\hline Trianthema decandra & $\mathrm{Ag}$ & Saponin & [74] \\
\hline
\end{tabular}


Table 1. Cont.

\begin{tabular}{|c|c|c|c|}
\hline Plant Species & NPs & Metabolites Identified in the Extract/NPs & Reference \\
\hline Aegle marmelos & $\mathrm{Ag}$ & Tannin & [75] \\
\hline Rosa rugosa & $\mathrm{Ag}$ & Carboxylate, amine groups & [76] \\
\hline Hibiscus rosa- sinensis & $\mathrm{Ag}$ & Carboxylate ion groups & [77] \\
\hline Leonuri herba & $\mathrm{Ag}$ & Hydroxyl, polyphenols groups & [78] \\
\hline Lonicera japonica & $\mathrm{Ag}$ & Phenolic and hydroxyl groups of chlorogenic acid & [79] \\
\hline Mangifera indica & $\mathrm{Ag}$ & Ketone, aldehydes, hydroxyl, carboxyl groups & {$[80]$} \\
\hline Eucalyptus & $\mathrm{Fe}$ & Alcohol, phenols, alkylaldehyde & [81] \\
\hline Alternanthera sessilis & $\mathrm{Ag}$ & Tannins, carbohydrates, proteins, ascorbic acid & {$[82]$} \\
\hline Boswellia serrata & $\mathrm{Ag}$ & Proteins & [83] \\
\hline Piper betle & $\mathrm{Ag}$ & Amide, aromatic amine & {$[84]$} \\
\hline Plumeria rubra & $\mathrm{Ag}$ & Proteins & [85] \\
\hline Jatropha curcas & $\mathrm{Ag}$ & Cyclic peptides (curcacycline A and curcacycline B) & [86] \\
\hline Hibiscus rosa- sinensis & $\mathrm{Au}$ & Flavonoids & [87] \\
\hline Vitis vinifera & $\mathrm{Au}$ & Flavonoids & [88] \\
\hline Mangifera indica & $\mathrm{Au}$ & Favonoids, terpenoids, thiamine & [89] \\
\hline Abutilon indicum & $\mathrm{Au}$ & Flavonoids, phenolic compounds & [90] \\
\hline Suaeda monoica & $\mathrm{Au}$ & Flavonoids, terpenoids, soluble proteins & [91] \\
\hline Sesbania grandiflora & $\mathrm{Au}$ & Flavonoids, polyphenols & [92] \\
\hline Citrus maxima & $\mathrm{Au}$ & Flavonoids, terpenes, vitamins & [93] \\
\hline Hypoxis hemerocallidea & $\mathrm{Au}$ & $\begin{array}{l}\text { Flavonoids, terpenoids, phenolic compounds and/or } \\
\text { carbohydrates }\end{array}$ & [94] \\
\hline Galenia africana & $\mathrm{Au}$ & $\begin{array}{l}\text { Flavonoids, terpenoids, phenolic compounds and/or } \\
\text { carbohydrates }\end{array}$ & [94] \\
\hline Nigella arvensis & $\mathrm{Au}$ & Flavonoids, phenolic compounds & [95] \\
\hline Butea monosperma & $\mathrm{Au}$ & Polyphenols & [96] \\
\hline Sterculia acuminata & $\mathrm{Au}$ & Polyphenols & [97] \\
\hline Terminalia arjuna & $\mathrm{Au}$ & Polyphenols & [98] \\
\hline Terminalia catappa & $\mathrm{Au}$ & Hydroxyl group of phenols & [99] \\
\hline Hygrophila spinosa & $\mathrm{Au}$ & Hydroxyl group & [100] \\
\hline Cassia auriculata & $\mathrm{Au}$ & Hydroxyl group & [101] \\
\hline Platycodon grandiflorum & $\mathrm{Au}$ & Hydroxyl group & [102] \\
\hline Phoenix dactylifera & $\mathrm{Au}$ & Hydroxyl group & [103] \\
\hline Lansium domesticum & $\mathrm{Au}$ & Carboxylic acid & [104] \\
\hline Salix alba & $\mathrm{Au}$ & $\begin{array}{l}\text { Proteins, metabolites having functional groups of amines, } \\
\text { alcohols, ketones, aldehydes, carboxylic acids (salicin) }\end{array}$ & [105] \\
\hline Cinnamomum zeylanicum & $\mathrm{Au}$ & Proteins & [39] \\
\hline Ficus benghalensis & $\mathrm{Au}$ & Proteins & [106] \\
\hline Jatropha & $\mathrm{Au}$ & Proteins & [16] \\
\hline Morinda citrifolia & $\mathrm{Au}$ & Proteins & [42] \\
\hline Gymnema sylvestre & $\mathrm{Au}$ & Proteins, polypeptides & [107] \\
\hline Olea europaea & $\mathrm{Au}$ & Proteins & {$[40]$} \\
\hline Trianthema decandra & $\mathrm{Au}$ & Saponin & {$[74]$} \\
\hline Terminalia arjuna & $\mathrm{Au}$ & Hydrolyzable tannins & [108] \\
\hline Elaeis guineensis & $\mathrm{Au}$ & Phenolic, carboxylic, amines & [109] \\
\hline Mentha piperita & $\mathrm{Au}$ & Menthol & [41] \\
\hline Argemone mexicana & $\mathrm{Au}$ & Phosphorous compounds & [110] \\
\hline Tamarindus indica & $\mathrm{Au}$ & Phenolic compounds & [111] \\
\hline Averrhoa bilimbi & $\mathrm{Au}$ & Phenols, tertiary amides & [112] \\
\hline Couroupita guianensis & $\mathrm{Au}$ & Phenol group & [113] \\
\hline Syzygium jambos & $\mathrm{Au}$ & Saccharides, phenolics & [114] \\
\hline Zostera noltii & $\mathrm{Au}$ & Flavone sulfates & [115] \\
\hline Ipomoea carnea & $\mathrm{Au}$ & Polysaccharides, protein & [116] \\
\hline Mirabilis jalapa & $\mathrm{Au}$ & Polysaccharides & {$[117]$} \\
\hline Panax ginseng & $\mathrm{Au}$ & Polysaccharides, phenolic compounds & [118] \\
\hline Galaxaura elongata & $\mathrm{Au}$ & $\begin{array}{l}\text { Glutamic acid, hexadecanoic acid, oleic acid, 11-eicosenoic } \\
\text { acid, stearic acid, gallic acid, epigallocatechin, catechin, } \\
\text { epicatechin gallate }\end{array}$ & [119] \\
\hline Tagetes sp. and Rosa sp. & $\mathrm{Cd}$ & $\begin{array}{l}\text { Alcoholic, amide, } \mathrm{C}-\mathrm{C},-\mathrm{OCH} 3 \text { groups (tannins, flavonoids, } \\
\text { alkaloids and carotenoids) }\end{array}$ & [120] \\
\hline Punica granatum & $\mathrm{Cu}$ & Flavonoids, alkaloids, polyphenols & [121] \\
\hline
\end{tabular}


Table 1. Cont.

\begin{tabular}{cclc}
\hline Plant Species & NPs & \multicolumn{1}{c}{ Metabolites Identified in the Extract/NPs } & Reference \\
\hline Cymbopogon citratus & $\mathrm{Cu}$ & Polyphenols, proteins & {$[122]$} \\
Lawsonia inermis & $\mathrm{Cu}$ & Phenolic compounds & {$[123]$} \\
Euphorbia granulate & $\mathrm{Pd}$ & Hydroxyflavones, phenolics & {$[124]$} \\
Hippophae rhamnoides & $\mathrm{Pd}$ & Flavonoids & {$[125]$} \\
Delonix regia & $\mathrm{Pd}$ & Polyphenols & {$[126]$} \\
Cacumen platycladi & $\mathrm{Pt}$ & Flavonoids, proteins & {$[127]$} \\
Diospyros kaki & $\mathrm{Pt}$ & Terpenoids & {$[128]$} \\
Dioscorea bulbifera & $\mathrm{Pt}-\mathrm{Pd}$ & Hydroxyl group of polyphenolic compounds & {$[129]$} \\
Cassia fistula & $\mathrm{ZnO}$ & Flavonoids, polyphenols & {$[130]$} \\
Azadirachta indica & $\mathrm{ZnO}$ & Flavonoids, phenolic acid, terpenoids, protein & {$[131]$} \\
Rosa canina & $\mathrm{ZnO}$ & Phenolic and carboxylic acids & {$[132]$} \\
Aloe barbadensis & $\mathrm{ZnO}$ & Phenol, amines, alcohol groups & {$[133]$} \\
Agathosma betulina & $\mathrm{ZnO}$ & Hydroxyl group & {$[134]$} \\
Trifolium pratense & $\mathrm{ZnO}$ & Hydroxyl group & {$[135]$} \\
Parthenium hysterophorus & $\mathrm{ZnO}$ & Phosphorus compound, secondary sulfonamide, & {$[136]$} \\
Anisochilus carnosus & $\mathrm{ZnO}$ & Phonosubstituted alkyne & {$[137]$} \\
Coptis chinensis & $\mathrm{ZnO}$ & Alcohol, carboxylic acid, alkyl halide, alkynes & {$[138]$} \\
Calotropis procera & $\mathrm{ZnO}$ & Hydroxyl groups, aldehydes, amines, ketones, carboxylic & {$[139]$} \\
\hline
\end{tabular}

Although researchers face significant challenges in identifying the elements participating in the green synthesis of NPs, Fourier-transform infrared spectroscopy (FT-IR) analyses have been used to obtain clues on the biomolecules possibly involved in the reduction of the metal ions and capping. A FT-IR analysis of Ag NPs synthesized using Acacia mearnsii bark extract suggested that compounds with hydroxyl, alkyne, carboxyl, and amide groups of the monoterpenoids, sesquiterpenes, and phytols might have participated in these processes [140]. Similar analysis of Au NPs green-synthesized using Suaeda monoica leaf extract indicated that the biomolecules with carboxyl, amine, and hydroxyl functional groups were involved in the reduction of $\mathrm{Au}$ ions [91]. Isolated flavonoids, terpenoids, chlorogenic acid, etc. have been successfully used in the green synthesis of NPs. Highly monodispersed (18.24 nm) spherical Au NPs could be synthesized using kaempferol as the in situ reductant and stabilizer [141]. The ability of terpenoid fractions isolated from Andrographis paniculata leaves for the green synthesis of $\mathrm{ZnO} N P s$ has also been demonstrated and confirmed by the presence of $\mathrm{C}=\mathrm{O}$ functional group in the NPs [142]. Au NPs were synthesized using chlorogenic acid as reductant, and the corresponding FT-IR spectra indicated that an $-\mathrm{OH}$ functional group was likely involved in the synthesis [143].

\section{Flavonoids are the Major Contributors of Green Synthesis of NPs}

High performance liquid chromatography (HPLC) analysis of Ag NPs green synthesized using Withania somnifera leaf extract revealed that several phenolic compounds present in the extract were selectively trapped in the Ag NPs [14]. On the basis of their characteristic UV-vis spectra and further confirmation by co-elution with pure standards, these compounds were identified as catechin, p-coumaric acid, and luteolin-7-glucoside. In addition, a major compound that appeared in the NPs was not found in the original extract, which might be a derivative resulting from the interaction of some withanolide derivatives with Ag ions.

Jain and Mehata [58] were able to green synthesize Ag NPs using both leaf extract of Ocimum sanctum and a flavonoid (quercetin) present in the extract separately. Their results revealed that both Ag NPs showed similar optical, morphological, and antibacterial characteristics, demonstrating that quercetin was responsible for the NP synthesis. Other flavonoids such as hesperidin, naringin, and diosmin have also been shown to be involved in the green synthesis of Ag NPs, with the size and shape distribution varied between the compounds. These authors concluded that the -OH group was involved in the reduction of Ag ions into Ag NPs [144]. 
Flavonoids are a family of natural polyphenolic compounds that include flavone, flavonol, flavanone, flavanonol, and isoflavone derivatives. The skeleton of flavonoids consists of two phenyl rings ( $\mathrm{A}$ and $\mathrm{B})$, connected by an oxygenated heterocycle ring $\mathrm{C}$, and is hydroxylated in several positions. These compounds have important roles in plants because they participate in the response to biotic and abiotic stresses [145]. Much attention has been paid to the chelating properties and antioxidative activities of natural flavonoids, as they are important for plant physiology and desirable for human health. A flavonoid-metal complex may be a target for ROS and free radicals. However, this complex can be a catalytic center for Fenton reaction and the ligand moiety may act as an acceptor for hydroxyl radical. It has been reported that the antioxidant activity of flavonoid-metal complexes is higher than that of free ligands [146,147].

The number of hydroxyl groups and the structure of flavonoids are important for metal-binding activity (Figure 4). Simple aglycones, such as chrysin, apigenin and genistein, may accept metal ion in one coordination pocket between the 4-carbonyl group and 5-hydroxyl group. Divalent metal ions $\mathrm{Cu}^{2+}, \mathrm{Co}^{2+}$, and $\mathrm{Ni}^{2+}$ are bound by two chrysin ligands [148]. Moreover, genistein and biochanin a chelate $\mathrm{Cu}^{2+}$ and $\mathrm{Fe}^{3+}$ with a 1:2 (metal:ligand) stoichiometry. Complexes of isoflavones with $\mathrm{Cu}$ have higher antioxidant potential than the free ligands, as revealed via 2,2-diphenyl-1-picrylhydrazyl (DPPH) reduction assays. Fe chelates were shown to have prooxidant potential [149]. In another report, apigenin was found to bind $\mathrm{Al}^{3+}$ and $\mathrm{Fe}^{2+}$ with a 1:3 (metal:ligand) stoichiometry in a dioxan water solution. In this case, the $4^{\prime}$-hydroxyl group was the coordination site [150]. Apigenin, naringenin, and hesperitin can chelate $\mathrm{Cu}$ ions and create coordination pocket between 4-carbonyl and 5-hydroxyl groups. Such complexes have a strong DNA-binding properties and cytotoxicity [151].
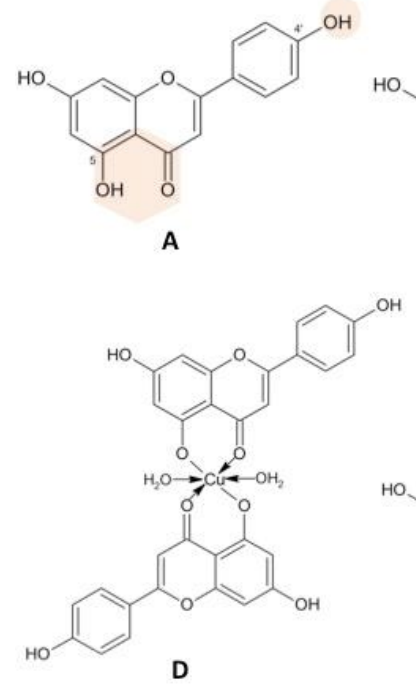

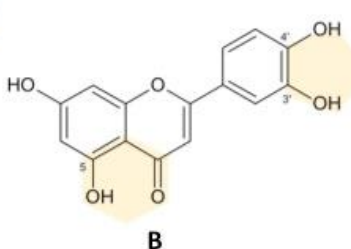

B

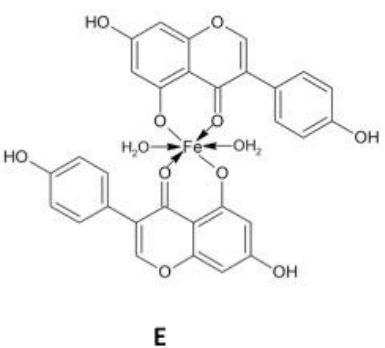

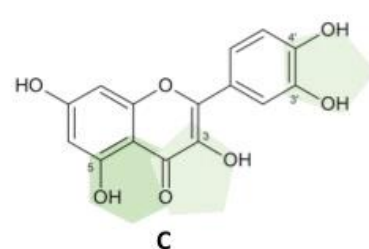

C

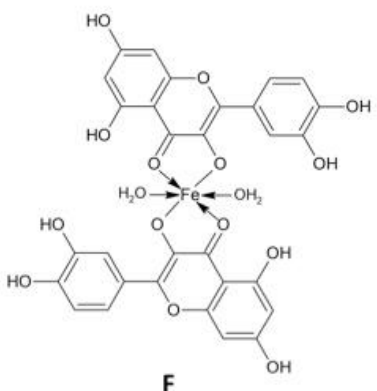

Figure 4. Metal-chelating properties of flavonoids.

Bicalein is a highly bioactive flavonoid that is characterized by three possible bidentate binding sites (4-carbonyl and three hydroxyl groups at carbons number 5, 6, 7). In this case, metal:bicalein complexes can be created by using only one binding site. Either hydroxyls at 5- and 6- carbon atoms or 6-hydroxyl-7-hydroxyl are potentially the binding sites of $\mathrm{Fe}^{2+}$ and $\mathrm{Fe}^{3+}$ ions, with a 1:1 and 1:2 stoichiometry. The Fe-bicalein complexes have high antioxidant properties due to inhibition of the Fenton reaction [152,153]. Similarly, two potential bidentate binding sites are present in the luteolin structure (5-hydroxyl-4-carbonyl and $3^{\prime} 4^{\prime}$-hydroxyl groups of the ring $\mathrm{B}$ ) and both sites can bind $\mathrm{Al}^{3+}$ ions in the molar ratio 2:1 (metal:ligand). The separation of the coordination pocket is important for increasing the chelating properties [154]. Quercetin has three potential bidendate binding places. The stable complexes of quercetin were reported for a large number of metal ions, such as $\mathrm{Fe}^{2+}, \mathrm{Fe}^{3+}$, $\mathrm{Cu}^{2+}, \mathrm{Zn}^{2+}, \mathrm{Co}^{2+}, \mathrm{Pb}^{2+}, \mathrm{Al}^{3+}$ [155]. 3-hydroxyl and 4-carbonyl groups of quercetin can chelate $\mathrm{Fe}^{2+}$ 
with a 1:2 (metal:ligand) stoichiometry. Quercetin-iron complex is characterised by high free radical scavenging, DNA binding and antibacterial activities [156].

Cherrak, et al. [33] reported on the chelating properties of quercetin, O-methylated quercetins, rutin, and catechin. The most stable complexes with $\mathrm{Fe}^{3+}, \mathrm{Zn}^{2+}$, and $\mathrm{Cu}^{2+}$ were observed for catechin, quercetin, and rutin compared to O-methylated analogues. Moreover, spectrophotometric studies of O-methylated quercetins showed the binding sequence with the iron ion: $3^{\prime} 4^{\prime}-\mathrm{OH}>3-\mathrm{OH}>>5-\mathrm{OH}[33]$. In summary, the modification of free hydroxyl groups in the flavonoids structure causes changes to both chelating and antioxidant properties. O-methylated flavonoids are weaker chelators than the free ligands. The aglycones have stronger antioxidant activities in comparison to the glycosides, e.g., baicalein-baicalin or luteolin-luteolin-4'-O-glucoside [147].

\section{Green-Synthesized NPs are Highly Bioactive and Biocompatible}

As discussed above, GNPs are often capped with secondary metabolites [14]. In addition to providing stability to the GNPs as capping agents or stabilizers, the presence of these compounds might enhance the bioactivities of these NPs (Table 2). The scavenging activities of Ag NPs prepared using three different natural polyphenols, epigallocatechin-3-gallate (EGCG), resveratrol (RSV), and fisetin, were highly correlated with their secondary metabolite content [157]. Green-synthesized Ag NPs using white rot fungi Pycnoporus broth showed better antimicrobial activity against the pathogenic bacteria in comparison to the chemically synthesized ones [158]. Microbiological tests performed using varying concentrations of green (aloe extract) and chemical $\mathrm{ZnO}$ NPs showed that green $\mathrm{ZnO}$ nanoparticles had enhanced biocidal activity against various pathogens compared to the chemical ZnO NPs [17]. It was observed that the green-synthesized Ag NPs using Salvadora persica root extract exhibited comparable or better antibacterial activities than the chemically obtained Ag NPs [18]. A bioactivity comparison of Ni NPs prepared via the chemical and green routes (Desmodium gangeticum aqueous root extract) suggested that NPs prepared by the green route had better antioxidant and antibacterial activity, without any toxicity towards epithelial cell line and Wistar rats [19].

Interestingly, green-synthesized ZnO NPs, which had been stabilized by plant metabolites, varied in their anti-diabetic activity based on their size in streptozotocin (STZ)-induced diabetic mice [20]. Au NPs synthesized using methanolic extract of Azolla microphylla showed excellent antioxidant activity [159]. Au NPs produced from Hypoxis hemerocallidea exhibited antibacterial activity against Staphylococcus aureus, Staphylococcus epidermidis, Escherichia coli, and Pseudomonas aeruginosa, whereas Au NPs produced from Galenia africana only exhibited antibacterial activity against P. aeruginosa [94]. The $\mathrm{Fe}_{3} \mathrm{O}_{4} \mathrm{NPs}$ synthesized using agro-waste extracts exhibited higher removal $(>90 \%)$ of antibiotics than $\mathrm{Fe}_{3} \mathrm{O}_{4}$ NPs synthesized by a conventional method [15]. The Cd NPs synthesized using marigold petal extracts showed better larvicidal activity against mosquito larvae compared to the Cd NPs synthesized using rose petal extracts [120]. An Azadirachta indica extract-mediated reduction of Ag ions resulted in the formation of different sizes of NPs $(4.74 \mathrm{~nm}$, $8.17 \mathrm{~nm}, 14.23 \mathrm{~nm}$, and 18.98) when the aqueous extract was not boiled [160], whereas the NPs prepared using boiled extract were of an average size of $34 \mathrm{~nm}$ [46]. Moreover, although the latter showed antibacterial activities against both gram positive and gram-negative bacteria, the former did not show activity against gram-positive bacteria.

Table 2. Bioactivities of green-synthesized NPs.

\begin{tabular}{cccc}
\hline NPs & Plant Species Used & Bioactivity Reported & Reference \\
\hline $\mathrm{Ag}$ & Withania somnifera & Antibacterial, anticandidal & {$[14]$} \\
$\mathrm{Ag}$ & Lansium domesticum & Antibacterial & {$[104]$} \\
$\mathrm{Ag}$ & Crocus satious & Antibacterial & {$[161]$} \\
$\mathrm{Ag}$ & Datura stramonium & Antibacterial & {$[162]$} \\
$\mathrm{Ag}$ & Prosopis glandulosa & Antibacterial & {$[163]$} \\
$\mathrm{Ag}$ & Azadirachta indica & Antibacterial & {$[46]$} \\
$\mathrm{Au}$ & Hypoxis hemerocallidea & Antibacterial & {$[94]$} \\
\hline
\end{tabular}


Table 2. Cont.

\begin{tabular}{|c|c|c|c|}
\hline NPs & Plant Species Used & Bioactivity Reported & Reference \\
\hline $\mathrm{Au}$ & Galenia africana & Antibacterial & [94] \\
\hline $\mathrm{Cu}$ & Terminalia catappa & Antibacterial & [164] \\
\hline Se & Azadirachta indica & Antibacterial & [165] \\
\hline $\mathrm{Pt}$ & Taraxacum laevigatum & Antibacterial & [166] \\
\hline $\mathrm{TiO}_{2}$ & Trigonella foenum-graecum & Antibacterial & [167] \\
\hline $\mathrm{Ag}_{2} \mathrm{O}$ & Ficus benghalensis & Antibacterial & [168] \\
\hline $\mathrm{Ag}$ & Pteris tripartita & Antibacterial, antifungal, antioxidant, antiinflammatory & [169] \\
\hline $\mathrm{Ag}$ & Phyllanthus amarus & Antibacterial & [170] \\
\hline $\mathrm{Ag}$ & Aloe arborescens & Antibacterial & [171] \\
\hline $\mathrm{Ag}$ & Syngonium podophyllum & Anticandidal & [172] \\
\hline $\mathrm{Ag}$ & Euphorbia prostrata & Antiplasmodial & [173] \\
\hline $\mathrm{Ag}$ & Ocimum sanctum & Antibacterial & [58] \\
\hline $\mathrm{Ag}$ & Hybanthus enneaspermus & Larvicidal & {$[64]$} \\
\hline $\mathrm{Ag}$ & Eclipta prostrata & Larvicidal & [174] \\
\hline $\mathrm{Cd}$ & Tagetes $s p$. and Rosa $s p$ & Larvicidal & [120] \\
\hline $\mathrm{Ag}$ & Holarrhena antidysenterica & Larvicidal & [175] \\
\hline $\mathrm{Ag}$ & Tinospora cordifolia & Larvicidal & [176] \\
\hline $\mathrm{Ag}$ & Chrysanthemum & Larvicidal & {$[177]$} \\
\hline $\mathrm{Ag}$ & Delonix elata & Wound healing & [178] \\
\hline $\mathrm{Ag}$ & Ficus krishnae & Antibacterial, anticancer & [179] \\
\hline $\mathrm{Ag}$ & Andrographis paniculata & Hepatocurative & [180] \\
\hline $\mathrm{Ag}$ & Lippia nodiflora & Antioxidant, antibacterial, cytotoxic & [181] \\
\hline $\mathrm{Ag}$ & Tragia involucrata & Antiurolithic & {$[182]$} \\
\hline $\mathrm{Ag}$ & Tagetes patula & Antifungal & [183] \\
\hline $\mathrm{Au}$ & Vetiveria zizanioides & Antifungal & [184] \\
\hline $\mathrm{Au}$ & Cannabis sativa & Antifungal & [184] \\
\hline $\mathrm{Ag}$ & Rauvolfia serpentina & Antimicrobial, larvicidal and cytotoxic & [185] \\
\hline $\mathrm{Au}$ & Cassia fistula & Antihypoglycemic & [186] \\
\hline $\mathrm{Au}$ & Terminalia chebula & Antifilarial & [187] \\
\hline $\mathrm{Au}$ & Euphorbia milii & Antinociceptive, muscle relaxant, sedative & [188] \\
\hline $\mathrm{Ag}$ & Rubus glaucus & Antioxidant & [189] \\
\hline $\mathrm{Au}$ & Punica Granatum & Antioxidant & [190] \\
\hline $\mathrm{Au}$ & Azolla microphylla & Antioxidant & [159] \\
\hline $\mathrm{CuO}$ & Morus alba & Antioxidant & [191] \\
\hline $\mathrm{CuO}$ & Olea europaea & Antioxidant & [192] \\
\hline $\mathrm{Au}$ & Acanthopanacis cortex & Anti-inflammatory & [193] \\
\hline $\mathrm{Au}$ & Allium sativum & Hepatoprotective & [194] \\
\hline $\mathrm{Au}$ & Trigonella foenum-graecum & Catalytic & [195] \\
\hline $\mathrm{CuO}$ & Cissus quadrangularis & Antifungal & {$[196]$} \\
\hline $\mathrm{CuO}$ & Ormocarpum cochinchinense & Anticancer & {$[197]$} \\
\hline $\mathrm{Pt}$ & Punica granatum & Cytotoxic & {$[198]$} \\
\hline $\mathrm{Pd}$ & Tinospora cordifolia & Antifilarial, antimalarial & {$[199]$} \\
\hline $\mathrm{Pd}$ & Pelargonium graveolens & Cytotoxic & {$[200]$} \\
\hline $\mathrm{Zn}$ & Cochlospermum religiosum & Antibacterial, antimitotic & {$[201]$} \\
\hline $\mathrm{Zn}$ & Momordica charantia & Acaricidal, pediculicidal, larvicidal & [202] \\
\hline $\mathrm{ZnO}$ & Ulva lactuca & Insecticidal & [203] \\
\hline $\mathrm{ZnO}$ & Hibiscus sabdariffa & Antibacterial, antidiabetic & {$[20]$} \\
\hline $\mathrm{ZnO}$ & Calotropis procera & Photocatalytic & {$[139]$} \\
\hline $\mathrm{Ni}$ & Desmodium gangeticum & Antioxidant, antibacterial & [19] \\
\hline $\mathrm{NiO}$ & Aegle marmelos & Cytotoxic, antibacterial & [204] \\
\hline $\mathrm{CeO}_{2}$ & Camellia sinensis & Healing of liver sepsis & [205] \\
\hline $\mathrm{TiO}_{2}$ & Parthenium hysterophorus & Larvicidal, antibacterial, photocatalytic & [206] \\
\hline $\mathrm{Fe}_{3} \mathrm{O}_{4}$ & Rosmarinus officinalis & Leishmanicidal & [207] \\
\hline $\mathrm{CeO}_{2}$ & Rubia cordifolia & Anticancer & {$[208]$} \\
\hline $\mathrm{Se}^{2}$ & Clausena dentata & Larvicidal & [209] \\
\hline $\mathrm{Au}$ & Salix alba & Antifungal, antinociceptive, muscle relaxant & [105] \\
\hline
\end{tabular}




\section{Potential Applications of Green-Synthesized NPs}

In addition to the several bioactivities listed above, GNPs also have been found to possess several industrial applications due to the presence of plant compounds (Table 3). For instance, enzymes are important biocatalysts in modern biotechnology but are highly unstable in nature. The thermal, $\mathrm{pH}$, and storage stability of $\alpha$-amylase could be improved by immobilization with naringin-functionalized magnetite nanoparticles [210]. Ag NPs synthesized using O. sanctum and Chenopodium aristatum showed good catalytic activity in degradation of 4-nitrophenol [21,22]. Similarly, Ag NPs synthesized using Thuja occidentalis extract could be used as a soil conditioner and plant growth promoter [211]. $\mathrm{Cu}$ NPs synthesized using Lawsonia inermis extract could be used to prepare electrical-conducting nanobiocomposites [123]. CuO NPs green-synthesized using Ocimum tenuiflorum extract could be used as non-enzymatic glucose biosensor [212].

Table 3. Secondary metabolites conjugated with NPs.

\begin{tabular}{cccc}
\hline $\mathbf{N P}$ & Source & Compound(s) Trapped/Conjugated & Reference \\
\hline $\mathrm{Ag}$ & Withania somnifera leaf extract & Catechin, p-coumaric acid, & {$[14]$} \\
$\mathrm{TiO}_{2}$ & Arabidopsis thaliana seedlings & and luteolin-7-glucoside and withanolides & {$[213]$} \\
$\mathrm{TiO}_{2}$ & Food samples & Flavonoids & {$[214]$} \\
$\mathrm{Fe}_{3} \mathrm{O}_{4}$ & Urine and blood & Myricetin & {$[215]$} \\
$\mathrm{TiO}_{2}$ & Flavonoids & Luteolin, quercetin, kaempferol & {$[216]$} \\
$\mathrm{TiO}_{2}-\mathrm{SiO}_{2}$ & Quercetin, rutin & Flavonoids & {$[217]$} \\
$\mathrm{TiO}_{2}-\mathrm{SiO}_{2}$ & Quercetin & Quercetin, rutin & {$[218]$} \\
$\mathrm{Au}$ & Baicalin & Quercetin & {$[219]$} \\
$\mathrm{Au}$ & Naringin & Baicalin & {$[220]$} \\
$\mathrm{Au}$ & Quercetin & Naringin & {$[221]$} \\
$\mathrm{Au}$ & Hesperetin & Quercetin & {$[222]$} \\
$\mathrm{Au}$ & Quercetin & Hesperetin & {$[223]$} \\
$\mathrm{Fe}_{3} \mathrm{O}_{4}$ & Quercetin & Quercetin & {$[224]$} \\
$\mathrm{Fe}_{3} \mathrm{O}_{4}$ & Naringin & Quercetin & {$[210]$} \\
\hline
\end{tabular}

The ability of plant secondary metabolites to chelate metal ions in the production of stable complexes and their potential to conjugate with NPs has opened a new window for NP use in harvesting these natural products. The ability to form a NP-secondary metabolite complex upon green synthesis provides us an opportunity to establish a relationship between NP type and compound classes, which would have impact on the nanoharvesting of compounds from live plants or tissues. During nanoharvesting, the metabolites are adsorbed onto the NPs and extrudes from plant cells to the medium and the metabolites can be separated through elution and magnetization [217]. Nanoharvesting eliminates the use of organic solvents, allows for the spectral identification of the isolated compounds, and provides new avenues for the use of nanomaterials for coupled isolation and testing of bioactive properties of plant-synthesized compounds.

Kurepa, et al. [213] showed that $\mathrm{TiO}_{2}$ NPs enter Arabidopsis thaliana plant cells, conjugate enediol and catechol group-rich flavonoids in situ, and exit plant cells as flavonoid-nanoparticle conjugates. The compound adsorption capacities of NPs could be further improved by functionalization [217]. For instance, adsorption capacity of $\mathrm{SiO}_{2} \mathrm{NPs}$ towards quercetin was higher upon $\mathrm{TiO}_{2}$ functionalization in comparison to non-functionalized and decyl group functionalized $\mathrm{SiO}_{2} \mathrm{NPs}$ due to possible binding of quercetin to the metal oxide [218]. This adsorption capacity increased linearly with surface coverage of $\mathrm{TiO}_{2}$, emphasizing the correlation between functional surface and quercetin adsorption. Similar to in vivo nanotrapping, in vitro green synthesis of NPs using plant extracts can be extended further to develop high throughput tools to extract specific classes of compounds from crude extracts (Figure 5). 


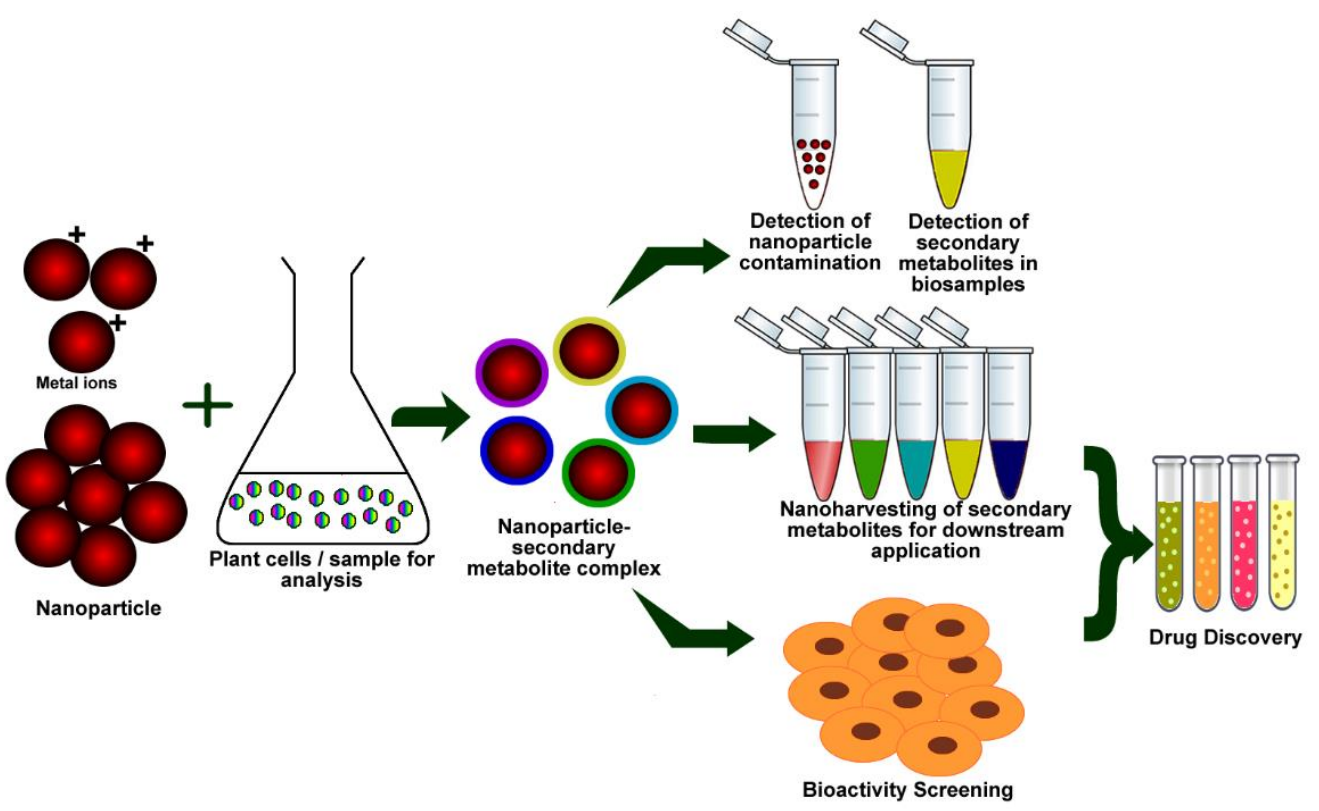

Figure 5. A scheme showing possible nanotrapping/nanoharvesting and drug discovery applications of green synthesis.

This NPs-secondary metabolite conjugation property can also be used in different fields of industrial biotechnology. Nanoparticle-mediated delivery of medicinally important flavonoids and other biomolecules will increase their therapeutic efficacy. As a potential drug delivery system, hesperitin-conjugated gold nanoparticles enhanced the treatment of hepatocellular carcinoma by minimizing the side effects and reduced the dose of chemotherapy drug [222]. Recently, several reports have addressed the potential risk of NPs to both human health and the environment, which necessitates a method to detect them in food and other samples. A green, facile, and rapid method using a flavonoid-assisted method was standardized to extract and detect the $\mathrm{TiO}_{2} \mathrm{NPs}$ in food samples [214]. It was also applicable in identifying flavonoid traces in biological samples, such as urine and blood [215].

\section{Conclusions}

Although the ability of extracts from diverse plant species to synthesize NPs could be explained by the widespread occurrence of polyphenolic compounds in the plant kingdom, a precise understanding of the green synthesis process is needed to realize the full potential of this process in medical and industrial applications. In spite of the facile synthesis of NPs via a green method, obtaining homogeneously dispersed NPs is a huge challenge, as several parameters including temperature, $\mathrm{pH}$ of the system, nature of the capping agent, concentration of active compounds, etc. might play vital roles in defining the size and morphology [225]. Au NPs synthesized using Cinnamomum zeylanicum leaf broth differed in their shape, which was based on the concentration of the extract [39]. At lower concentrations of the extract, the formation of prism-shaped NPs dominated and, at higher concentrations however, mostly spherical NPs were formed [39]. Hence, reducing, capping, or stabilizing agents participating in the green synthesis need to be further analyzed to specify the NP structural relationship.

A high-throughput analysis of plant extracts with diverse metal ions would provide clues as to whether there is any correlation between the specific compounds and the NPs generated. This would have a huge potential in the trapping of compounds and proteins using metal ions or NPs, which are difficult or expensive to purify by other means. NPs green-synthesized using medicinal plant extracts should be tested for various bioactivities in comparison with their chemically or physically synthesized 
counterparts to understand whether the bioactivities observed could be attributed to the presence of capping agents in the NPs. Considering that NPs bioactivities also differ between their size shape and zeta potential, similar NPs needs to be compared. For example, in spite of excellent antibacterial activities reported against antibiotic resistant strains, it is not clear whether this is a result of the NPs, the compounds attached to them, both, or, conversely, a result of the other compounds present in the extract; such comparisons require further study.

In the light of above discussion, it has been extensively reported that GNPs surface chemistry is helpful in the advancement of biomedical applications. However, most studies have shown that GNPs are subjected to calcinations using a blast furnace at ultra high temperatures [225-227] to attain the highest level of crystalline morphology before they can be used. This will surely provide a pure-phase crystalline structure, but the surface-attached phytochemicals as capping agents will be decomposed. Accordingly, to achieve GNPs with functionalized surfaces and sticky capping agents for advanced biological applications, we must improve the synthesis modes.

Funding: This research was funded by Narodowym Centrum Nauki (NCN), Poland grant number UMO-2016/21/B/NZ9/01980 and the APC was funded by European Union's 7th Framework Programme for research, technological development, and demonstration under grant agreement No. 621321 and co-financed by funds allocated for education through project No. W26/7.PR/2015 [GA 3413/7.PR/2015/2] for the years 2015-2019.

Acknowledgments: Qaisar Maqbool and Dariusz Kruszka are supported by PhD grants from NCN projects UMO-2016/23/B/NZ9/02677 and UMO-2016/21/B/NZ9/01980 respectively. Rajendran Kamalabai Selvakesavan is a recipient of postdoc grant from UMO-2016/21/B/NZ9/01980.

Conflicts of Interest: The authors declare no conflict of interest.

\section{References}

1. Agarwal, H.; Venkat Kumar, S.; Rajeshkumar, S. A review on green synthesis of zinc oxide nanoparticles-An eco-friendly approach. Resour. Effic. Technol. 2017, 3, 406-413. [CrossRef]

2. Prasad, R.; Bhattacharyya, A.; Nguyen, Q.D. Nanotechnology in sustainable agriculture: Recent developments, challenges, and perspectives. Front. Microbiol. 2017, 8, 1014 . [CrossRef] [PubMed]

3. Dimkpa, C.O.; Bindraban, P.S. Nanofertilizers: New Products for the Industry? J. Agric. Food Chem. 2017. [CrossRef] [PubMed]

4. Fayaz, A.M.; Balaji, K.; Girilal, M.; Yadav, R.; Kalaichelvan, P.T.; Venketesan, R. Biogenic synthesis of silver nanoparticles and their synergistic effect with antibiotics: A study against gram-positive and gram-negative bacteria. Nanomed. Nanotechnol. Biol. Med. 2010, 6, 103-109. [CrossRef] [PubMed]

5. Gómez-Graña, S.; Perez-Ameneiro, M.; Vecino, X.; Pastoriza-Santos, I.; Perez-Juste, J.; Cruz, J.; Moldes, A. Biogenic synthesis of metal nanoparticles using a biosurfactant extracted from corn and their antimicrobial properties. Nanomaterials 2017, 7, 139. [CrossRef] [PubMed]

6. Narayanan, K.B.; Sakthivel, N. Biological synthesis of metal nanoparticles by microbes. Adv. Colloid Interface Sci. 2010, 156, 1-13. [CrossRef] [PubMed]

7. Gardea-Torresdey, J.L.; Parsons, J.G.; Gomez, E.; Peralta-Videa, J.; Troiani, H.E.; Santiago, P.; Yacaman, M.J. Formation and growth of Au nanoparticles inside live alfalfa plants. Nano Lett. 2002, 2, 397-401. [CrossRef]

8. Gardea-Torresdey, J.L.; Gomez, E.; Peralta-Videa, J.R.; Parsons, J.G.; Troiani, H.; Jose-Yacaman, M. Alfalfa sprouts: A natural source for the synthesis of silver nanoparticles. Langmuir 2003, 19, 1357-1361. [CrossRef]

9. Harris, A.T.; Bali, R. On the formation and extent of uptake of silver nanoparticles by live plants. J. Nanopart. Res. 2008, 10, 691-695. [CrossRef]

10. Haverkamp, R.G.; Marshall, A.T. The mechanism of metal nanoparticle formation in plants: Limits on accumulation. J. Nanopart. Res. 2009, 11, 1453-1463. [CrossRef]

11. Roh, K.-H.; Kwak, B.-K.; Kim, J.-B.; Lee, K.-R.; Kim, H.-U.; Kim, S.-H. The influence of silver thiosulfate and thidiazuron on shoot regeneration from cotyledon explants of Brassica napus. J. Plant Biotechnol. 2012, 39, 133-139. [CrossRef] 
12. Kumari, R.; Singh, J.S.; Singh, D.P. Biogenic synthesis and spatial distribution of silver nanoparticles in the legume mungbean plant (Vigna radiata L.). Plant Physiol. Biochem. 2017, 110, 158-166. [CrossRef] [PubMed]

13. Vineet, K.; Kumar, Y.S. Plant-mediated synthesis of silver and gold nanoparticles and their applications. J. Chem. Technol. Biotechnol. 2009, 84, 151-157.

14. Marslin, G.; Selvakesavan, R.K.; Franklin, G.; Sarmento, B.; Dias, A.C. Antimicrobial activity of cream incorporated with silver nanoparticles biosynthesized from Withania somnifera. Int. J. Nanomed. 2015, 10, 5955-5963.

15. Stan, M.; Lung, I.; Soran, M.-L.; Leostean, C.; Popa, A.; Stefan, M.; Lazar, M.D.; Opris, O.; Silipas, T.-D.; Porav, A.S. Removal of antibiotics from aqueous solutions by green synthesized magnetite nanoparticles with selected agro-waste extracts. Proc. Saf. Environ. Prot. 2017, 107, 357-372. [CrossRef]

16. Kanchi, S.; Kumar, G.; Lo, A.-Y.; Tseng, C.-M.; Chen, S.-K.; Lin, C.-Y.; Chin, T.-S. Exploitation of de-oiled jatropha waste for gold nanoparticles synthesis: A green approach. Arab. J. Chem. 2018, 11, 247-255. [CrossRef]

17. Gunalan, S.; Sivaraj, R.; Rajendran, V. Green synthesized ZnO nanoparticles against bacterial and fungal pathogens. Prog. Nat. Sci. Mater. Int. 2012, 22, 693-700. [CrossRef]

18. Shaik, M.; Albalawi, G.; Khan, S.; Khan, M.; Adil, S.; Kuniyil, M.; Al-Warthan, A.; Siddiqui, M.; Alkhathlan, H.; Khan, M. "Miswak" based green synthesis of silver nanoparticles: Evaluation and comparison of their microbicidal activities with the chemical synthesis. Molecules 2016, 21, 1478. [CrossRef] [PubMed]

19. Sudhasree, S.; Shakila Banu, A.; Brindha, P.; Kurian, G.A. Synthesis of nickel nanoparticles by chemical and green route and their comparison in respect to biological effect and toxicity. Toxicol. Environ. Chem. 2014, 96, 743-754. [CrossRef]

20. Bala, N.; Saha, S.; Chakraborty, M.; Maiti, M.; Das, S.; Basu, R.; Nandy, P. Green synthesis of zinc oxide nanoparticles using Hibiscus subdariffa leaf extract: Effect of temperature on synthesis, anti-bacterial activity and anti-diabetic activity. RSC Adv. 2015, 5, 4993-5003. [CrossRef]

21. Singh, J.; Mehta, A.; Rawat, M.; Basu, S. Green synthesis of silver nanoparticles using sun dried tulsi leaves and its catalytic application for 4-Nitrophenol reduction. J. Environ. Chem. Eng. 2018, 6, 1468-1474. [CrossRef]

22. Yuan, C.-G.; Huo, C.; Gui, B.; Liu, P.; Zhang, C. Green synthesis of silver nanoparticles using Chenopodium aristatum L. stem extract and their catalytic/antibacterial activities. J. Clust. Sci. 2017, 28, 1319-1333. [CrossRef]

23. Anjum, N.A.; Hasanuzzaman, M.; Hossain, M.A.; Thangavel, P.; Roychoudhury, A.; Gill, S.S.; Rodrigo, M.A.M.; Adam, V.; Fujita, M.; Kizek, R.; et al. Jacks of metal/metalloid chelation trade in plants-An overview. Front. Plant Sci. 2015, 6, 192. [CrossRef] [PubMed]

24. Hasan, M.K.; Cheng, Y.; Kanwar, M.K.; Chu, X.-Y.; Ahammed, G.J.; Qi, Z.-Y. Responses of Plant Proteins to Heavy Metal Stress-A Review. Front. Plant Sci. 2017, 8, 1492. [CrossRef] [PubMed]

25. Simão, B.N.; Cristiano, S.; Alexandra, S.; Viviana, M.; Manuel, A.; Hernâni, G.; Fernanda, F. An efficient antioxidant system and heavy metal exclusion from leaves make Solanum cheesmaniae more tolerant to $\mathrm{Cu}$ than its cultivated counterpart. Food Energy Secur. 2017, 6, 123-133.

26. Marslin, G.; Sheeba, C.J.; Franklin, G. Nanoparticles alter secondary metabolism in plants via ROS burst. Front. Plant Sci. 2017, 8, 832. [CrossRef] [PubMed]

27. Franklin, G.; Conceição, L.F.R.; Kombrink, E.; Dias, A.C.P. Xanthone biosynthesis in Hypericum perforatum cells provides antioxidant and antimicrobial protection upon biotic stress. Phytochemistry 2009, 70, 60-68. [CrossRef] [PubMed]

28. Singh, S.; Parihar, P.; Singh, R.; Singh, V.P.; Prasad, S.M. Heavy metal tolerance in plants: Role of transcriptomics, proteomics, metabolomics, and ionomics. Front. Plant Sci. 2016, 6, 1143. [CrossRef] [PubMed]

29. Pham, H.N.; Michalet, S.; Bodillis, J.; Nguyen, T.D.; Nguyen, T.K.O.; Le, T.P.Q.; Haddad, M.; Nazaret, S.; Dijoux-Franca, M.-G. Impact of metal stress on the production of secondary metabolites in Pteris vittata L. and associated rhizosphere bacterial communities. Environ. Sci. Pollut. Res. 2017, 24, 16735-16750. [CrossRef] [PubMed]

30. Winkel-Shirley, B. Biosynthesis of flavonoids and effects of stress. Curr. Opin. Plant Biol. 2002, 5, $218-223$. [CrossRef] 
31. Díaz, J.; Bernal, A.; Pomar, F.; Merino, F. Induction of shikimate dehydrogenase and peroxidase in pepper (Capsicum annuиm L.) seedlings in response to copper stress and its relation to lignification. Plant Sci. 2001, 161, 179-188. [CrossRef]

32. Jun, M.; Fu, H.Y.; Hong, J.; Wan, X.; Yang, C.S.; Ho, C.T. Comparison of antioxidant activities of isoflavones from kudzu root (Pueraria lobata Ohwi). J. Food Sci. 2003, 68, 2117-2122. [CrossRef]

33. Cherrak, S.A.; Mokhtari-Soulimane, N.; Berroukeche, F.; Bensenane, B.; Cherbonnel, A.; Merzouk, H.; Elhabiri, M. In vitro antioxidant versus metal ion chelating properties of flavonoids: A structure-activity investigation. PLoS ONE 2016, 11, e0165575. [CrossRef] [PubMed]

34. Matile, P. Das toxische Kompartiment der Pflanzenzelle. Naturwissenschaften 1984, 71, 18-24. [CrossRef]

35. Zhao, J. Flavonoid transport mechanisms: How to go, and with whom. Trends Plant Sci. 2015, 20, 576-585. [CrossRef] [PubMed]

36. Marinova, K.; Pourcel, L.; Weder, B.; Schwarz, M.; Barron, D.; Routaboul, J.-M.; Debeaujon, I.; Klein, M. The Arabidopsis MATE transporter $\mathrm{TT}_{12}$ acts as a vacuolar flavonoid $/ \mathrm{H}^{+}$-antiporter active in proanthocyanidin-accumulating cells of the seed coat. Plant Cell 2007, 19, 2023. [CrossRef] [PubMed]

37. Manceau, A.; Nagy, K.L.; Marcus, M.A.; Lanson, M.; Geoffroy, N.; Jacquet, T.; Kirpichtchikova, T. Formation of metallic copper nanoparticles at the soil-root interface. Environ. Sci. Technol. 2008, 42, 1766-1772. [CrossRef] [PubMed]

38. Makarov, V.V.; Love, A.J.; Sinitsyna, O.V.; Makarova, S.S.; Yaminsky, I.V.; Taliansky, M.E.; Kalinina, N.O. “Green" nanotechnologies: Synthesis of metal nanoparticles dsing plants. Acta Nat. 2014, 6, 35-44.

39. Smitha, S.L.; Philip, D.; Gopchandran, K.G. Green synthesis of gold nanoparticles using Cinnamomum zeylanicum leaf broth. Spectrochim. Acta A Mol. Biomol. Spectrosc. 2009, 74, 735-739. [CrossRef] [PubMed]

40. Khalil, M.M.H.; Ismail, E.H.; El-Magdoub, F. Biosynthesis of Au nanoparticles using olive leaf extract: 1st Nano Updates. Arab. J. Chem. 2012, 5, 431-437. [CrossRef]

41. MubarakAli, D.; Thajuddin, N.; Jeganathan, K.; Gunasekaran, M. Plant extract mediated synthesis of silver and gold nanoparticles and its antibacterial activity against clinically isolated pathogens. Colloids Surf. B Biointerfaces 2011, 85, 360-365. [CrossRef] [PubMed]

42. Suman, T.Y.; Radhika Rajasree, S.R.; Ramkumar, R.; Rajthilak, C.; Perumal, P. The Green synthesis of gold nanoparticles using an aqueous root extract of Morinda citrifolia L. Spectrochim. Acta A Mol. Biomol. Spectrosc. 2014, 118, 11-16. [CrossRef] [PubMed]

43. Gole, A.; Dash, C.; Ramakrishnan, V.; Sainkar, S.R.; Mandale, A.B.; Rao, M.; Sastry, M. Pepsin-gold colloid conjugates: Preparation, characterization, and enzymatic activity. Langmuir 2001, 17, 1674-1679. [CrossRef]

44. Vanaja, M.; Annadurai, G. Coleus aromaticus leaf extract mediated synthesis of silver nanoparticles and its bactericidal activity. Appl. Nanosci. 2013, 3, 217-223. [CrossRef]

45. Prasad, R.; Swamy, V.S. Antibacterial activity of silver nanoparticles synthesized by bark extract of Syzygium cumini. J. Nanoparticles 2013, 2013, 6. [CrossRef]

46. Ahmed, S.; Saifullah; Ahmad, M.; Swami, B.L.; Ikram, S. Green synthesis of silver nanoparticles using Azadirachta indica aqueous leaf extract. J. Radiat. Res. Appl. Sci. 2016, 9, 1-7. [CrossRef]

47. Kaviya, S.; Santhanalakshmi, J.; Viswanathan, B.; Muthumary, J.; Srinivasan, K. Biosynthesis of silver nanoparticles using Citrus sinensis peel extract and its antibacterial activity. Spectrochim. Acta A Mol. Biomol. Spectrosc. 2011, 79, 594-598. [CrossRef] [PubMed]

48. Velmurugan, P.; Anbalagan, K.; Manosathyadevan, M.; Lee, K.J.; Cho, M.; Lee, S.M.; Park, J.H.; Oh, S.G.; Bang, K.S.; Oh, B.T. Green synthesis of silver and gold nanoparticles using Zingiber officinale root extract and antibacterial activity of silver nanoparticles against food pathogens. Bioprocess Biosyst. Eng. 2014, 37, 1935-1943. [CrossRef] [PubMed]

49. Ramteke, C.; Chakrabarti, T.; Sarangi, B.K.; Pandey, R.-A. Synthesis of silver nanoparticles from the aqueous extract of leaves of Ocimum sanctum for enhanced antibacterial activity. J. Chem. 2013, 2013, 7. [CrossRef]

50. Dinesh, S.; Karthikeyan, S.; Arumugam, P. Biosynthesis of silver nanoparticles from Glycyrrhiza glabra root extract. Arch Appl. Sci. Res. 2012, 4, 178-187.

51. Chahardoli, A.; Karimi, N.; Fattahi, A. Biosynthesis, characterization, antimicrobial and cytotoxic effects of silver nanoparticles using Nigella arvensis seed extract. Iran. J. Pharm. Res. 2017, 16, 1167-1175. [PubMed]

52. Ghosh, S.; Patil, S.; Ahire, M.; Kitture, R.; Kale, S.; Pardesi, K.; Cameotra, S.S.; Bellare, J.; Dhavale, D.D.; Jabgunde, A.; et al. Synthesis of silver nanoparticles using Dioscorea bulbifera tuber extract and evaluation of its synergistic potential in combination with antimicrobial agents. Int. J. Nanomed. 2012, 7, 483-496. 
53. Ajitha, B.; Ashok Kumar Reddy, Y.; Shameer, S.; Rajesh, K.M.; Suneetha, Y.; Sreedhara Reddy, P. Lantana camara leaf extract mediated silver nanoparticles: Antibacterial, green catalyst. J. Photochem. Photobiol. B 2015, 149, 84-92. [CrossRef] [PubMed]

54. Thakore, S.; Rathore, P.S.; Jadeja, R.N.; Thounaojam, M.; Devkar, R.V. Sunflower oil mediated biomimetic synthesis and cytotoxicity of monodisperse hexagonal silver nanoparticles. Mater. Sci. Eng. C 2014, 44, 209-215. [CrossRef] [PubMed]

55. Ghaedi, M.; Yousefinejad, M.; Safarpoor, M.; Khafri, H.Z.; Purkait, M.K. Rosmarinus officinalis leaf extract mediated green synthesis of silver nanoparticles and investigation of its antimicrobial properties. J. Ind. Eng. Chem. 2015, 31, 167-172. [CrossRef]

56. Kiran Kumar, H.A.; Mandal, B.K.; Mohan Kumar, K.; Maddinedi, S. b.; Sai Kumar, T.; Madhiyazhagan, P.; Ghosh, A.R. Antimicrobial and antioxidant activities of Mimusops elengi seed extract mediated isotropic silver nanoparticles. Spectrochim. Acta A Mol. Biomol. Spectrosc. 2014, 130, 13-18. [CrossRef] [PubMed]

57. Kumar, V.; Yadav, S.C.; Yadav, S.K. Syzygium cumini leaf and seed extract mediated biosynthesis of silver nanoparticles and their characterization. J. Chem. Technol. Biotechnol. 2010, 85, 1301-1309. [CrossRef]

58. Jain, S.; Mehata, M.S. Medicinal plant leaf extract and pure flavonoid mediated green synthesis of silver nanoparticles and their enhanced antibacterial property. Sci. Rep. 2017, 7, 15867. [CrossRef] [PubMed]

59. Krishnaraj, C.; Jagan, E.G.; Rajasekar, S.; Selvakumar, P.; Kalaichelvan, P.T.; Mohan, N. Synthesis of silver nanoparticles using Acalypha indica leaf extracts and its antibacterial activity against water borne pathogens. Colloids Surf. B Biointerfaces 2010, 76, 50-56. [CrossRef] [PubMed]

60. LÜ, F.; Gao, Y.; Huang, J.; Sun, D.; Li, Q. Roles of biomolecules in the biosynthesis of silver nanoparticles: Case of Gardenia jasminoides extract. Chin. J. Chem. Eng. 2014, 22, 706-712. [CrossRef]

61. Cruz, D.; Fale, P.L.; Mourato, A.; Vaz, P.D.; Serralheiro, M.L.; Lino, A.R. Preparation and physicochemical characterization of Ag nanoparticles biosynthesized by Lippia citriodora (Lemon Verbena). Colloids Surf. B Biointerfaces 2010, 81, 67-73. [CrossRef] [PubMed]

62. Rashmi, V.; Sanjay, K.R. Green synthesis, characterisation and bioactivity of plant-mediated silver nanoparticles using Decalepis hamiltonii root extract. IET Nanobiotechnol. 2017, 11, 247-254. [CrossRef] [PubMed]

63. Elumalai, D.; Kaleena, P.K.; Ashok, K.; Suresh, A.; Hemavathi, M. Green synthesis of silver nanoparticle using Achyranthes aspera and its larvicidal activity against three major mosquito vectors. Eng. Agric. Environ. Food 2016, 9, 1-8. [CrossRef]

64. Suman, T.Y.; Rajasree, S.R.R.; Jayaseelan, C.; Mary, R.R.; Gayathri, S.; Aranganathan, L.; Remya, R.R. GC-MS analysis of bioactive components and biosynthesis of silver nanoparticles using Hybanthus enneaspermus at room temperature evaluation of their stability and its larvicidal activity. Environ. Sci. Pollut. Res. 2016, 23, 2705-2714. [CrossRef] [PubMed]

65. Ahmad, N.; Sharma, S.; Singh, V.N.; Shamsi, S.F.; Fatma, A.; Mehta, B.R. Biosynthesis of Silver Nanoparticles from Desmodium triflorum: A Novel Approach Towards Weed Utilization. Biotechnol. Res. Int. 2011, 2011, 454090. [CrossRef] [PubMed]

66. Nabikhan, A.; Kandasamy, K.; Raj, A.; Alikunhi, N.M. Synthesis of antimicrobial silver nanoparticles by callus and leaf extracts from saltmarsh plant, Sesuvium portulacastrum L. Colloids Surf. B Biointerfaces 2010, 79, 488-493. [CrossRef] [PubMed]

67. Sengottaiyan, A.; Mythili, R.; Selvankumar, T.; Aravinthan, A.; Kamala-Kannan, S.; Manoharan, K.; Thiyagarajan, P.; Govarthanan, M.; Kim, J.-H. Green synthesis of silver nanoparticles using Solanum indicum L. and their antibacterial, splenocyte cytotoxic potentials. Res. Chem. Int. 2016, 42, 3095-3103. [CrossRef]

68. Mukunthan, K.S.; Balaji, S. Cashew apple juice (Anacardium occidentale L.) speeds up the synthesis of silver nanoparticles. Int. J. Green Nanotechnol. 2012, 4, 71-79. [CrossRef]

69. Dipankar, C.; Murugan, S. The green synthesis, characterization and evaluation of the biological activities of silver nanoparticles synthesized from Iresine herbstii leaf aqueous extracts. Colloids Surf. B Biointerfaces 2012, 98, 112-119. [CrossRef] [PubMed]

70. Geethalakshmi, R.; Sarada, D.V. Synthesis of plant-mediated silver nanoparticles using Trianthema decandra extract and evaluation of their antimicrobial activities. Int. J. Eng. Sci. Technol. 2010, 2, 970-975.

71. Kumar, K.R.; Nattuthurai, N.; Gopinath, P.; Mariappan, T. Synthesis of eco-friendly silver nanoparticles from Morinda tinctoria leaf extract and its larvicidal activity against Culex quinquefasciatus. Parasitol. Res. 2015, 114, 411-417. [CrossRef] [PubMed] 
72. Banala, R.R.; Nagati, V.B.; Karnati, P.R. Green synthesis and characterization of Carica papaya leaf extract coated silver nanoparticles through X-ray diffraction, electron microscopy and evaluation of bactericidal properties. Saudi J. Biol. Sci. 2015, 22, 637-644. [CrossRef] [PubMed]

73. Vivek, R.; Thangam, R.; Muthuchelian, K.; Gunasekaran, P.; Kaveri, K.; Kannan, S. Green biosynthesis of silver nanoparticles from Annona squamosa leaf extract and its in vitro cytotoxic effect on MCF-7 cells. Process Biochem. 2012, 47, 2405-2410. [CrossRef]

74. Geethalakshmi, R.; Sarada, D.V.L. Characterization and antimicrobial activity of gold and silver nanoparticles synthesized using saponin isolated from Trianthema decandra L. Ind. Crops Products 2013, 51, 107-115.

75. Jagajjanani Rao, K.; Paria, S. Green synthesis of silver nanoparticles from aqueous Aegle marmelos leaf extract. Mater. Res. Bull. 2013, 48, 628-634. [CrossRef]

76. Dubey, S.P.; Lahtinen, M.; Sillanpää, M. Green synthesis and characterizations of silver and gold nanoparticles using leaf extract of Rosa rugosa. Colloids Surf. A Physicochem. Eng. Asp. 2010, 364, 34-41. [CrossRef]

77. Nayak, D.; Ashe, S.; Rauta, P.R.; Nayak, B. Biosynthesis, characterisation and antimicrobial activity of silver nanoparticles using Hibiscus rosa-sinensis petals extracts. IET Nanobiotechnol. 2015, 9, 288-293. [CrossRef] [PubMed]

78. Im, A.R.; Han, L.; Kim, E.R.; Kim, J.; Kim, Y.S.; Park, Y. Enhanced antibacterial activities of Leonuri herba extracts containing silver nanoparticles. Phytother. Res. 2012, 26, 1249-1255. [CrossRef] [PubMed]

79. Zhou, Y.; Tang, R.-C. Facile and eco-friendly fabrication of AgNPs coated silk for antibacterial and antioxidant textiles using honeysuckle extract. J. Photochem. Photobiol. B Biol. 2018, 178, 463-471. [CrossRef] [PubMed]

80. Yang, N.; Li, W.-H. Mango peel extract mediated novel route for synthesis of silver nanoparticles and antibacterial application of silver nanoparticles loaded onto non-woven fabrics. Ind. Crops Prod. 2013, 48, 81-88. [CrossRef]

81. Liu, Y.; Jin, X.; Chen, Z. The formation of iron nanoparticles by Eucalyptus leaf extract and used to remove Cr(VI). Sci. Total Environ. 2018, 627, 470-479. [CrossRef] [PubMed]

82. Niraimathi, K.L.; Sudha, V.; Lavanya, R.; Brindha, P. Biosynthesis of silver nanoparticles using Alternanthera sessilis (Linn.) extract and their antimicrobial, antioxidant activities. Colloids Surf. B Biointerfaces 2013, 102, 288-291. [CrossRef] [PubMed]

83. Kora, A.J.; Sashidhar, R.B.; Arunachalam, J. Aqueous extract of gum olibanum (Boswellia serrata): A reductant and stabilizer for the biosynthesis of antibacterial silver nanoparticles. Process Biochem. 2012, 47, 1516-1520. [CrossRef]

84. Lagashetty, A.N. Green synthesis and characterization of silver nanoparticles using Piper betel leaf extract. Bull. Adv. Sci. Res. 2015, 1, 136-138.

85. Patil, C.D.; Patil, S.V.; Borase, H.P.; Salunke, B.K.; Salunkhe, R.B. Larvicidal activity of silver nanoparticles synthesized using Plumeria rubra plant latex against Aedes aegypti and Anopheles stephensi. Parasitol. Res. 2012, 110, 1815-1822. [CrossRef] [PubMed]

86. Bar, H.; Bhui, D.K.; Sahoo, G.P.; Sarkar, P.; De, S.P.; Misra, A. Green synthesis of silver nanoparticles using latex of Jatropha curcas. Colloids Surf. A Physicochem. Eng. Asp. 2009, 339, 134-139. [CrossRef]

87. Yasmin, A.; Ramesh, K.; Rajeshkumar, S. Optimization and stabilization of gold nanoparticles by using herbal plant extract with microwave heating. Nano Converg. 2014, 1, 12. [CrossRef] [PubMed]

88. Khalil, M. Biosynthesis of gold nanoparticles using extract of grape (Vitis vinifera) leaves and seeds. Prog. Nanotechnol. Nanomater. 2014, 3, 1-12.

89. Philip, D. Rapid green synthesis of spherical gold nanoparticles using Mangifera indica leaf. Spectrochim. Acta A Mol. Biomol. Spectrosc. 2010, 77, 807-810. [CrossRef] [PubMed]

90. Mata, R.; Nakkala, J.R.; Sadras, S.R. Polyphenol stabilized colloidal gold nanoparticles from Abutilon indicum leaf extract induce apoptosis in HT-29 colon cancer cells. Colloids Surf. B Biointerfaces 2016, 143, 499-510. [CrossRef] [PubMed]

91. Rajathi, F.A.A.; Arumugam, R.; Saravanan, S.; Anantharaman, P. Phytofabrication of gold nanoparticles assisted by leaves of Suada monoica and its free radical scavenging property. J. Photochem. Photobiol. B Biol. 2014, 135, 75-80. [CrossRef] [PubMed]

92. Das, J.; Velusamy, P. Catalytic reduction of methylene blue using biogenic gold nanoparticles from Sesbania grandiflora L. J. Taiwan Inst. Chem. Eng. 2014, 45, 2280-2285. [CrossRef] 
93. Yu, J.; Xu, D.; Guan, H.N.; Wang, C.; Huang, L.K.; Chi, D.F. Facile one-step green synthesis of gold nanoparticles using Citrus maxima aqueous extracts and its catalytic activity. Mater. Lett. 2016, 166, 110-112. [CrossRef]

94. Elbagory, A.M.; Meyer, M.; Cupido, C.N.; Hussein, A.A. Inhibition of bacteria associated with wound infection by biocompatible green synthesized gold nanoparticles from South African plant extracts. Nanomaterials 2017, 7, 417. [CrossRef] [PubMed]

95. Chahardoli, A.; Karimi, N.; Sadeghi, F.; Fattahi, A. Green approach for synthesis of gold nanoparticles from Nigella arvensis leaf extract and evaluation of their antibacterial, antioxidant, cytotoxicity and catalytic activities. Artif. Cells Nanomed. Biotechnol. 2018, 46, 579-588. [CrossRef] [PubMed]

96. Patra, S.; Mukherjee, S.; Barui, A.K.; Ganguly, A.; Sreedhar, B.; Patra, C.R. Green synthesis, characterization of gold and silver nanoparticles and their potential application for cancer therapeutics. Mater. Sci. Eng. C 2015, 53, 298-309. [CrossRef] [PubMed]

97. Bogireddy, N.K.R.; Hoskote Anand, K.K.; Mandal, B.K. Gold nanoparticles—Synthesis by Sterculia acuminata extract and its catalytic efficiency in alleviating different organic dyes. J. Mol. Liq. 2015, 211, 868-875. [CrossRef]

98. Mohan Kumar, K.; Mandal, B.K.; Kiran Kumar, H.A.; Maddinedi, S.B. Green synthesis of size controllable gold nanoparticles. Spectrochim. Acta A Mol. Biomol. Spectrosc. 2013, 116, 539-545. [CrossRef] [PubMed]

99. Ankamwar, B. Biosynthesis of gold nanoparticles (Green-gold) using leaf extract of Terminalia catappa. E J. Chem. 2010, 7, 1334-1339. [CrossRef]

100. Koperuncholan, $\mathrm{M}$. Bioreduction of chloroauric acid $\left(\mathrm{HAuCl}_{4}\right)$ for the synthesis of gold nanoparticles (GNPs): A special empathies of pharmacological activity. Int. J. Phytopharm. 2015, 5, 72-80.

101. Venkatachalam, M.; Govindaraju, K.; Mohamed Sadiq, A.; Tamilselvan, S.; Ganesh Kumar, V.; Singaravelu, G. Functionalization of gold nanoparticles as antidiabetic nanomaterial. Spectrochim. Acta A Mol. Biomol. Spectrosc. 2013, 116, 331-338. [CrossRef] [PubMed]

102. Choi, Y.; Kang, S.; Cha, S.H.; Kim, H.S.; Song, K.; Lee, Y.J.; Kim, K.; Kim, Y.S.; Cho, S.; Park, Y. Platycodon saponins from Platycodi Radix (Platycodon grandiflorum) for the green synthesis of gold and silver nanoparticles. Nanoscale Res. Lett. 2018, 13, 018-2436. [CrossRef] [PubMed]

103. Zayed, M.F.; Eisa, W.H. Phoenix dactylifera L. leaf extract phytosynthesized gold nanoparticles; controlled synthesis and catalytic activity. Spectrochim. Acta A Mol. Biomol. Spectrosc. 2014, 121, 238-244. [CrossRef] [PubMed]

104. Shankar, S.; Jaiswal, L.; Aparna, R.S.L.; Prasad, R.G.S.V. Synthesis, characterization, in vitro biocompatibility, and antimicrobial activity of gold, silver and gold silver alloy nanoparticles prepared from Lansium domesticum fruit peel extract. Mater. Lett. 2014, 137, 75-78. [CrossRef]

105. Islam, N.U.; Jalil, K.; Shahid, M.; Rauf, A.; Muhammad, N.; Khan, A.; Shah, M.R.; Khan, M.A. Green synthesis and biological activities of gold nanoparticles functionalized with Salix alba. Arab. J. Chem. 2015. [CrossRef]

106. Francis, G.; Thombre, R.; Parekh, F.; Leksminarayan, P. Bioinspired Synthesis of Gold Nanoparticles Using Ficus benghalensis (Indian Banyan) Leaf Extract. Chem. Sci. Trans. 2014, 2014, 470-474.

107. Arunachalam, K.D.; Arun, L.B.; Annamalai, S.K.; Arunachalam, A.M. Biofunctionalized gold nanoparticles synthesis from gymnema sylvestre and its preliminary anticancer activity. Int. J. Pharm. Pharm. Sci. 2014, 6, 423-430.

108. Gopinath, K.; Venkatesh, K.S.; Ilangovan, R.; Sankaranarayanan, K.; Arumugam, A. Green synthesis of gold nanoparticles from leaf extract of Terminalia arjuna, for the enhanced mitotic cell division and pollen germination activity. Ind. Crops Prod. 2013, 50, 737-742. [CrossRef]

109. Ahmad, T.; Bustam, M.A.; Irfan, M.; Moniruzzaman, M.; Anwaar Asghar, H.M.; Bhattacharjee, S. Green synthesis of stabilized spherical shaped gold nanoparticles using novel aqueous Elaeis guineensis (oil palm) leaves extract. J. Mol. Struct. 2018, 1159, 167-173. [CrossRef]

110. Varun, S.; Sivakumar, S.; Rafiqkhan, M.; Vijayakumar, S. Green synthesis of gold nanoparticles using Argemone mexicana L. Leaf extract and its characterization. Int. J. Pharm. Sci. Rev. Res. 2015, 32, 42-44.

111. Correa, S.N.; Naranjo, A.M.; Herrera, A.P. Biosynthesis and characterization of gold nanoparticles using extracts of Tamarindus indica L. Leaves. J. Phys. Conf. Ser. 2016, 687, 012082. [CrossRef]

112. Isaac, R.S.R.; Sakthivel, G.; Murthy, C. Green synthesis of gold and silver nanoparticles using Averrhoa bilimbi fruit extract. J. Nanotechnol. 2013, 2013, 6. [CrossRef] 
113. Sathishkumar, G.; Jha, P.K.; Vignesh, V.; Rajkuberan, C.; Jeyaraj, M.; Selvakumar, M.; Jha, R.; Sivaramakrishnan, S. Cannonball fruit (Couroupita guianensis, Aubl.) extract mediated synthesis of gold nanoparticles and evaluation of its antioxidant activity. J. Mol. Liq. 2016, 215, 229-236.

114. Dutta, P.P.; Bordoloi, M.; Gogoi, K.; Roy, S.; Narzary, B.; Bhattacharyya, D.R.; Mohapatra, P.K.; Mazumder, B. Antimalarial silver and gold nanoparticles: Green synthesis, characterization and in vitro study. Biomed. Pharmacother. 2017, 91, 567-580. [CrossRef] [PubMed]

115. Zarzuela, R.; Luna, M.J.; Gil, M.L.A.; Ortega, M.J.; Palacios-Santander, J.M.; Naranjo-Rodríguez, I.; Delgado, J.J.; Cubillana-Aguilera, L.M. Analytical determination of the reducing and stabilization agents present in different Zostera noltii extracts used for the biosynthesis of gold nanoparticles. J. Photochem. Photobiol. B Biol. 2018, 179, 32-38. [CrossRef] [PubMed]

116. Abbasi, T.; Anuradha, J.; Ganaie, S.U.; Abbasi, S.A. Gainful utilization of the highly intransigent weed ipomoea in the synthesis of gold nanoparticles. J. King Saud Univ. Sci. 2015, 27, 15-22. [CrossRef]

117. Vankar, P.S.; Bajpai, D. Preparation of gold nanoparticles from Mirabilis jalapa flowers. Indian J. Biochem. Biophys. 2010, 47, 157-160. [PubMed]

118. Jimenez Perez, Z.E.; Mathiyalagan, R.; Markus, J.; Kim, Y.J.; Kang, H.M.; Abbai, R.; Seo, K.H.; Wang, D.; Soshnikova, V.; Yang, D.C. Ginseng-berry-mediated gold and silver nanoparticle synthesis and evaluation of their in vitro antioxidant, antimicrobial, and cytotoxicity effects on human dermal fibroblast and murine melanoma skin cell lines. Int. J. Nanomed. 2017, 12, 709-723. [CrossRef] [PubMed]

119. Abdel-Raouf, N.; Al-Enazi, N.M.; Ibraheem, I.B.M. Green biosynthesis of gold nanoparticles using Galaxaura elongata and characterization of their antibacterial activity. Arab. J. Chem. 2017, 10, S3029-S3039. [CrossRef]

120. Hajra, A.; Dutta, S.; Mondal, N.K. Mosquito larvicidal activity of cadmium nanoparticles synthesized from petal extracts of marigold (Tagetes sp.) and rose (Rosa sp.) flower. J. Parasit. Dis. Off. Organ Indian Soc. Parasitol. 2016, 40, 1519-1527. [CrossRef] [PubMed]

121. Nazar, N.; Bibi, I.; Kamal, S.; Iqbal, M.; Nouren, S.; Jilani, K.; Umair, M.; Ata, S. Cu nanoparticles synthesis using biological molecule of $P$. granatum seeds extract as reducing and capping agent: Growth mechanism and photo-catalytic activity. Int. J. Biol. Macromol. 2018, 106, 1203-1210. [CrossRef] [PubMed]

122. Brumbaugh, A.D.; Cohen, K.A.; St. Angelo, S.K. Ultrasmall copper nanoparticles synthesized with a plant eea reducing agent. ACS Sustain. Chem. Eng. 2014, 2, 1933-1939. [CrossRef]

123. Cheirmadurai, K.; Biswas, S.; Murali, R.; Thanikaivelan, P. Green synthesis of copper nanoparticles and conducting nanobiocomposites using plant and animal sources. RSC Adv. 2014, 4, 19507-19511. [CrossRef]

124. Nasrollahzadeh, M.; Mohammad Sajadi, S. Pd nanoparticles synthesized in situ with the use of Euphorbia granulate leaf extract: Catalytic properties of the resulting particles. J. Colloid Interface Sci. 2016, 462, $243-251$. [CrossRef] [PubMed]

125. Nasrollahzadeh, M.; Sajadi, S.M.; Maham, M. Green synthesis of palladium nanoparticles using Hippophae rhamnoides Linn leaf extract and their catalytic activity for the Suzuki-Miyaura coupling in water. J. Mol. Catal. A Chem. 2015, 396, 297-303. [CrossRef]

126. Dauthal, P.; Mukhopadhyay, M. Biosynthesis of palladium nanoparticles using Delonix regia leaf extract and its catalytic activity for nitro-aromatics hydrogenation. Ind. Eng. Chem. Res. 2013, 52, 18131-18139. [CrossRef]

127. Zheng, B.; Kong, T.; Jing, X.; Odoom-Wubah, T.; Li, X.; Sun, D.; Lu, F.; Zheng, Y.; Huang, J.; Li, Q. Plant-mediated synthesis of platinum nanoparticles and its bioreductive mechanism. J. Colloid Interface Sci. 2013, 396, 138-145. [CrossRef] [PubMed]

128. Song, J.Y.; Kwon, E.Y.; Kim, B.S. Biological synthesis of platinum nanoparticles using Diopyros kaki leaf extract. Bioprocess Biosyst. Eng. 2010, 33, 159-164. [CrossRef] [PubMed]

129. Ghosh, S.; Nitnavare, R.; Dewle, A.; Tomar, G.B.; Chippalkatti, R.; More, P.; Kitture, R.; Kale, S.; Bellare, J.; Chopade, B.A. Novel platinum-palladium bimetallic nanoparticles synthesized by Dioscorea bulbifera: Anticancer and antioxidant activities. Int. J. Nanomed. 2015, 10, 7477-7790.

130. Suresh, D.; Nethravathi, P.C.; Udayabhanu; Rajanaika, H.; Nagabhushana, H; Sharma, S.C. Green synthesis of multifunctional zinc oxide ( $\mathrm{ZnO})$ nanoparticles using Cassia fistula plant extract and their photodegradative, antioxidant and antibacterial activities. Mater. Sci. Semicond. Process. 2015, 31, 446-454. [CrossRef]

131. Elumalai, K.; Velmurugan, S. Green synthesis, characterization and antimicrobial activities of zinc oxide nanoparticles from the leaf extract of Azadirachta indica (L.). Appl. Surf. Sci. 2015, 345, 329-336. [CrossRef] 
132. Jafarirad, S.; Mehrabi, M.; Divband, B.; Kosari-Nasab, M. Biofabrication of zinc oxide nanoparticles using fruit extract of Rosa canina and their toxic potential against bacteria: A mechanistic approach. Mater. Sci. Eng. C 2016, 59, 296-302. [CrossRef] [PubMed]

133. Ali, K.; Dwivedi, S.; Azam, A.; Saquib, Q.; Al-Said, M.S.; Alkhedhairy, A.A.; Musarrat, J. Aloe vera extract functionalized zinc oxide nanoparticles as nanoantibiotics against multi-drug resistant clinical bacterial isolates. J. Colloid Interface Sci. 2016, 472, 145-156. [CrossRef] [PubMed]

134. Thema, F.T.; Manikandan, E.; Dhlamini, M.S.; Maaza, M. Green synthesis of ZnO nanoparticles via Agathosma betulina natural extract. Mater. Lett. 2015, 161, 124-127. [CrossRef]

135. Dobrucka, R.; Dlugaszewska, J. Biosynthesis and antibacterial activity of ZnO nanoparticles using Trifolium pratense flower extract. Saudi J. Biol. Sci. 2016, 23, 517-523. [CrossRef] [PubMed]

136. Rajiv, P.; Rajeshwari, S.; Venckatesh, R. Bio-fabrication of zinc oxide nanoparticles using leaf extract of Parthenium hysterophorus L. and its size-dependent antifungal activity against plant fungal pathogens. Spectrochim. Acta A Mol. Biomol. Spectrosc. 2013, 112, 384-387. [CrossRef] [PubMed]

137. Anbuvannan, M.; Ramesh, M.; Viruthagiri, G.; Shanmugam, N.; Kannadasan, N. Anisochilus carnosus leaf extract mediated synthesis of zinc oxide nanoparticles for antibacterial and photocatalytic activities. Mater. Sci. Semicond. Process. 2015, 39, 621-628. [CrossRef]

138. Nagajyothi, P.C.; Sreekanth, T.V.M.; Tettey, C.O.; Jun, Y.I.; Mook, S.H. Characterization, antibacterial, antioxidant, and cytotoxic activities of $\mathrm{ZnO}$ nanoparticles using Coptidis Rhizoma. Bioorgan. Med. Chem. Lett. 2014, 24, 4298-4303. [CrossRef] [PubMed]

139. Gawade, V.V.; Gavade, N.L.; Shinde, H.M.; Babar, S.B.; Kadam, A.N.; Garadkar, K.M. Green synthesis of $\mathrm{ZnO}$ nanoparticles by using Calotropis procera leaves for the photodegradation of methyl orange. J. Mater. Sci. Mater. Electron. 2017, 28, 14033-14039. [CrossRef]

140. Avoseh, O.N.; Oyedeji, O.O.; Aremu, O.; Nkeh-Chungag, B.N.; Songca, S.P.; Oyedeji, A.O.; Mohan, S.; Oluwafemi, O.S. Biosynthesis of silver nanoparticles from Acacia mearnsii De Wild stem bark and its antinociceptive properties. Green Chem. Lett. Rev. 2017, 10, 59-68. [CrossRef]

141. Halder, A.; Das, S.; Bera, T.; Mukherjee, A. Rapid synthesis for monodispersed gold nanoparticles in kaempferol and anti-leishmanial efficacy against wild and drug resistant strains. RSC Adv. 2017, 7, 14159-14167. [CrossRef]

142. Kavitha, S.; Dhamodaran, M.; Prasad, R.; Ganesan, M. Synthesis and characterisation of zinc oxide nanoparticles using terpenoid fractions of Andrographis paniculata leaves. Int. Nano Lett. 2017, 7, 141-147. [CrossRef]

143. Hwang, S.J.; Jun, S.H.; Park, Y.; Cha, S.-H.; Yoon, M.; Cho, S.; Lee, H.-J.; Park, Y. Green synthesis of gold nanoparticles using chlorogenic acid and their enhanced performance for inflammation. Nanomed. Nanotechnol. Biol. Med. 2015, 11, 1677-1688. [CrossRef] [PubMed]

144. Sahu, N.; Soni, D.; Chandrashekhar, B.; Satpute, D.B.; Saravanadevi, S.; Sarangi, B.K.; Pandey, R.A. Synthesis of silver nanoparticles using flavonoids: Hesperidin, naringin and diosmin, and their antibacterial effects and cytotoxicity. Int. Nano Lett. 2016, 6, 173-181. [CrossRef]

145. Kachlicki, P.; Piasecka, A.; Stobiecki, M.; Marczak, Ł. Structural Characterization of Flavonoid Glycoconjugates and Their Derivatives with Mass Spectrometric Techniques. Molecules 2016, 21, 1494. [CrossRef] [PubMed]

146. Kostyuk, V.A.; Potapovich, A.I.; Kostyuk, T.V.; Cherian, M.G. Metal complexes of dietary flavonoids: Evaluation of radical scavenger properties and protective activity against oxidative stress in vivo. Cell Mol. Biol. 2007, 53, 62-69. [PubMed]

147. Samsonowicz, M.; Regulska, E.; Kalinowska, M. Hydroxyflavone metal complexes-Molecular structure, antioxidant activity and biological effects. Chem. Biol. Interact. 2017, 273, 245-256. [CrossRef] [PubMed]

148. Pusz, J.; Nitka, B. Synthesis and physicochemical properties of the complexes of Co(II), Ni(II), and Cu(II) with chrysin. Microchem. J. 1997, 56, 373-381. [CrossRef]

149. Dowling, S.; Regan, F.; Hughes, H. The characterisation of structural and antioxidant properties of isoflavone metal chelates. J. Inorg. Biochem. 2010, 104, 1091-1098. [CrossRef] [PubMed]

150. Erdogan, G.; Karadag, R.; Eler, A. Aluminium(III), Fe(II) complexes and dyeing properties of apigenin(5,7, $4^{\prime}$-trihydroxy flavone). Rev. Anal. Chem. 2010, 29, 211-232. [CrossRef] 
151. Tan, M.; Zhu, J.; Pan, Y.; Chen, Z.; Liang, H.; Liu, H.; Wang, H. Synthesis, cytotoxic activity, and DNA binding properties of Copper (II) complexes with hesperetin, naringenin, and apigenin. Bioinorg. Chem. Appl. 2009, 2009, 347872. [CrossRef] [PubMed]

152. Perez, C.A.; Wei, Y.; Guo, M. Iron-binding and anti-Fenton properties of baicalein and baicalin. J. Inorg. Biochem. 2009, 103, 326-332. [CrossRef] [PubMed]

153. Dimitrić Marković, J.M.; Marković, Z.S.; Brdarić, T.P.; Pavelkić, V.M.; Jadranin, M.B. Iron complexes of dietary flavonoids: Combined spectroscopic and mechanistic study of their free radical scavenging activity. Food Chem. 2011, 129, 1567-1577. [CrossRef]

154. Rygula, A.; Wrobel, T.P.; Szklarzewicz, J.; Baranska, M. Raman and UV-vis spectroscopy studies on luteolin-Al(III) complexes. Vib. Spectrosc. 2013, 64, 21-26. [CrossRef]

155. Leopoldini, M.; Russo, N.; Toscano, M. The molecular basis of working mechanism of natural polyphenolic antioxidants. Food Chem. 2011, 125, 288-306. [CrossRef]

156. Raza, A.; Xu, X.; Xia, L.; Xia, C.; Tang, J.; Ouyang, Z. Quercetin-Iron complex: Synthesis, characterization, antioxidant, DNA binding, DNA cleavage, and antibacterial activity studies. J. Fluoresc. 2016, 26, 2023-2031. [CrossRef] [PubMed]

157. Sanna, V.; Pala, N.; Dessi, G.; Manconi, P.; Mariani, A.; Dedola, S.; Rassu, M.; Crosio, C.; Iaccarino, C.; Sechi, M. Single-step green synthesis and characterization of gold-conjugated polyphenol nanoparticles with antioxidant and biological activities. Int. J. Nanomed. 2014, 9, 4935-4951.

158. Gudikandula, K.; Charya Maringanti, S. Synthesis of silver nanoparticles by chemical and biological methods and their antimicrobial properties. J. Exp. Nanosci. 2016, 11, 714-721. [CrossRef]

159. Kunjiappan, S.; Chowdhury, R.; Bhattacharjee, C. A green chemistry approach for the synthesis and characterization of bioactive gold nanoparticles using Azolla microphylla methanol extract. Front. Mater. Sci. 2014, 8, 123-135. [CrossRef]

160. Nazeruddin, G.M.; Prasad, N.R.; Waghmare, S.R.; Garadkar, K.M.; Mulla, I.S. Extracellular biosynthesis of silver nanoparticle using Azadirachta indica leaf extract and its anti-microbial activity. J. Alloys Compd. 2014, 583, 272-277. [CrossRef]

161. Bagherzade, G.; Tavakoli, M.M.; Namaei, M.H. Green synthesis of silver nanoparticles using aqueous extract of saffron (Crocus sativus L.) wastages and its antibacterial activity against six bacteria. Asian Pac. J. Trop. Biomed. 2017, 7, 227-233. [CrossRef]

162. Gomathi, M.; Rajkumar, P.V.; Prakasam, A.; Ravichandran, K. Green synthesis of silver nanoparticles using Datura stramonium leaf extract and assessment of their antibacterial activity. Resour. Eff. Technol. 2017, 3, 280-284. [CrossRef]

163. Abdelmoteleb, A.; Valdez-Salas, B.; Ceceña-Duran, C.; Tzintzun-Camacho, O.; Gutiérrez-Miceli, F.; Grimaldo-Juarez, O.; González-Mendoza, D. Silver nanoparticles from Prosopis glandulosa and their potential application as biocontrol of Acinetobacter calcoaceticus and Bacillus cereus. Chem. Speciat. Bioavailab. 2017, 29, 1-5. [CrossRef]

164. Muthulakshmi, L.; Rajini, N.; Nellaiah, H.; Kathiresan, T.; Jawaid, M.; Rajulu, A.V. Preparation and properties of cellulose nanocomposite films with in situ generated copper nanoparticles using Terminalia catappa leaf extract. Int. J. Biol. Macromol. 2017, 95, 1064-1071. [CrossRef] [PubMed]

165. Tareq, F.K.; Fayzunnesa, M.; Kabir, M.S.; Nuzat, M. Mechanism of bio molecule stabilized selenium nanoparticles against oxidation process and Clostridium Botulinum. Microb. Pathog. 2018, 115, 68-73. [CrossRef] [PubMed]

166. Tahir, K.; Nazir, S.; Ahmad, A.; Li, B.; Khan, A.U.; Khan, Z.U.; Khan, F.U.; Khan, Q.U.; Khan, A.; Rahman, A.U. Facile and green synthesis of phytochemicals capped platinum nanoparticles and in vitro their superior antibacterial activity. J. Photochem. Photobiol. B 2017, 166, 246-251. [CrossRef] [PubMed]

167. Subhapriya, S.; Gomathipriya, P. Green synthesis of titanium dioxide $\left(\mathrm{TiO}_{2}\right)$ nanoparticles by Trigonella foenum-graecum extract and its antimicrobial properties. Microb. Pathog. 2018, 116, 215-220. [CrossRef] [PubMed]

168. Manikandan, V.; Velmurugan, P.; Park, J.-H.; Chang, W.-S.; Park, Y.-J.; Jayanthi, P.; Cho, M.; Oh, B.-T. Green synthesis of silver oxide nanoparticles and its antibacterial activity against dental pathogens. 3 Biotech 2017, 7, 72. [CrossRef] [PubMed] 
169. Baskaran, X.; Geo Vigila, A.V.; Parimelazhagan, T.; Muralidhara-Rao, D.; Zhang, S. Biosynthesis, characterization, and evaluation of bioactivities of leaf extract-mediated biocompatible silver nanoparticles from an early tracheophyte, Pteris tripartita Sw. Int. J. Nanomed. 2016, 11, 5789-5806. [CrossRef] [PubMed]

170. Singh, K.; Panghal, M.; Kadyan, S.; Chaudhary, U.; Yadav, J.P. Green silver nanoparticles of Phyllanthus amarus: As an antibacterial agent against multi drug resistant clinical isolates of Pseudomonas aeruginosa. J. Nanobiotechnol. 2014, 12, 40. [CrossRef] [PubMed]

171. Kumar, S.S.D.; Houreld, N.N.; Kroukamp, E.M.; Abrahamse, H. Cellular imaging and bactericidal mechanism of green-synthesized silver nanoparticles against human pathogenic bacteria. J. Photochem. Photobiol. B Biol. 2018, 178, 259-269. [CrossRef] [PubMed]

172. Yasir, M.; Singh, J.; Tripathi, M.K.; Singh, P.; Shrivastava, R. Green synthesis of silver nanoparticles using leaf extract of common arrowhead houseplant and its anticandidal activity. Pharmacogn. Mag. 2018, 13 (Suppl. 4), S840-S844. [PubMed]

173. Zahir, A.A.; Rahuman, A.A. Evaluation of different extracts and synthesised silver nanoparticles from leaves of Euphorbia prostrata against Haemaphysalis bispinosa and Hippobosca maculata. Vet. Parasitol. 2012, 187, 511-520. [CrossRef] [PubMed]

174. Rajakumar, G.; Abdul Rahuman, A. Larvicidal activity of synthesized silver nanoparticles using Eclipta prostrata leaf extract against filariasis and malaria vectors. Acta Tropica 2011, 118, 196-203. [CrossRef] [PubMed]

175. Kumar, D.; Kumar, G.; Das, R.; Agrawal, V. Strong larvicidal potential of silver nanoparticles (AgNPs) synthesized using Holarrhena antidysenterica (L.) Wall. bark extract against malarial vector, Anopheles stephensi Liston. Process Saf. Environ. Prot. 2018, 116, 137-148. [CrossRef]

176. Jayaseelan, C.; Rahuman, A.A.; Rajakumar, G.; Vishnu Kirthi, A.; Santhoshkumar, T.; Marimuthu, S.; Bagavan, A.; Kamaraj, C.; Zahir, A.A.; Elango, G. Synthesis of pediculocidal and larvicidal silver nanoparticles by leaf extract from heartleaf moonseed plant, Tinospora cordifolia Miers. Parasitol. Res. 2011, 109, 185-194. [CrossRef] [PubMed]

177. Ghramh, H.A.; Al-Ghamdi, K.M.; Mahyoub, J.A.; Ibrahim, E.H. Chrysanthemum extract and extract prepared silver nanoparticles as biocides to control Aedes aegypti (L.), the vector of dengue fever. J. Asia Pac. Entomol. 2018, 21, 205-210. [CrossRef]

178. Chai, S.H.; Wang, Y.; Qiao, Y.; Wang, P.; Li, Q.; Xia, C.; Ju, M. Bio fabrication of silver nanoparticles as an effective wound healing agent in the wound care after anorectal surgery. J. Photochem. Photobiol. B 2018, 178, 457-462. [CrossRef] [PubMed]

179. Kanjikar, A.P.; Hugar, A.L.; Londonkar, R.L. Characterization of phyto-nanoparticles from Ficus krishnae for their antibacterial and anticancer activities. Drug Dev. Ind. Pharm. 2018, 44, 377-384. [CrossRef] [PubMed]

180. Suriyakalaa, U.; Antony, J.J.; Suganya, S.; Siva, D.; Sukirtha, R.; Kamalakkannan, S.; Pichiah, P.B.; Achiraman, S. Hepatocurative activity of biosynthesized silver nanoparticles fabricated using Andrographis paniculata. Colloids Surf. B Biointerfaces 2013, 102, 189-194. [CrossRef] [PubMed]

181. Sudha, A.; Jeyakanthan, J.; Srinivasan, P. Green synthesis of silver nanoparticles using Lippia nodiflora aerial extract and evaluation of their antioxidant, antibacterial and cytotoxic effects. Resour. Eff. Technol. 2017, 3, 506-515. [CrossRef]

182. Velu, V.; Das, M.; Dua, K.; Malipeddi, H. Evaluation of in vitro and in vivo anti-urolithiatic activity of silver nanoparticles containing aqueous leaf extract of Tragia involucrata. Drug Deliv. Transl. Res. 2017, 7, 439-449. [CrossRef] [PubMed]

183. Sukhwal, A.; Jain, D.; Joshi, A.; Rawal, P.; Kushwaha, H.S. Biosynthesised silver nanoparticles using aqueous leaf extract of Tagetes patula L. and evaluation of their antifungal activity against phytopathogenic fungi. IET Nanobiotechnol. 2017, 11, 531-537. [CrossRef] [PubMed]

184. Swain, S.; Barik, S.K.; Behera, T.; Nayak, S.K.; Sahoo, S.K.; Mishra, S.S.; Swain, P. Green synthesis of gold nanoparticles using root and leaf extracts of Vetiveria zizanioides and Cannabis sativa and its antifungal activities. BioNanoScience 2016, 6, 205-213. [CrossRef]

185. Panja, S.; Chaudhuri, I.; Khanra, K.; Bhattacharyya, N. Biological application of green silver nanoparticle synthesized from leaf extract of Rauvolfia serpentina Benth. Asian Pac. J. Trop. Dis. 2016, 6, 549-556. [CrossRef]

186. Daisy, P.; Saipriya, K. Biochemical analysis of Cassia fistula aqueous extract and phytochemically synthesized gold nanoparticles as hypoglycemic treatment for diabetes mellitus. Int. J. Nanomed. 2012, 7, 1189-1202. [CrossRef] [PubMed] 
187. Roy, P.; Saha, S.K.; Gayen, P.; Chowdhury, P.; Sinha Babu, S.P. Exploration of antifilarial activity of gold nanoparticle against human and bovine filarial parasites: A nanomedicinal mechanistic approach. Colloids Surf. B Biointerfaces 2018, 161, 236-243. [CrossRef] [PubMed]

188. Islam, N.U.; Khan, I.; Rauf, A.; Muhammad, N.; Shahid, M.; Shah, M.R. Antinociceptive, muscle relaxant and sedative activities of gold nanoparticles generated by methanolic extract of Euphorbia milii. BMC Complement Altern. Med. 2015, 15, 160. [CrossRef] [PubMed]

189. Kumar, B.; Smita, K.; Cumbal, L.; Debut, A. Green synthesis of silver nanoparticles using Andean blackberry fruit extract. Saudi J. Biol. Sci. 2017, 24, 45-50. [CrossRef] [PubMed]

190. Gubitosa, J.; Rizzi, V.; Lopedota, A.; Fini, P.; Laurenzana, A.; Fibbi, G.; Fanelli, F.; Petrella, A.; Laquintana, V.; Denora, N.; et al. One pot environmental friendly synthesis of gold nanoparticles using Punica Granatum Juice: A novel antioxidant agent for future dermatological and cosmetic applications. J. Colloid Interface Sci. 2018, 521, 50-61. [CrossRef] [PubMed]

191. Singh, A.; Singh, N.B.; Hussain, I.; Singh, H. Effect of biologically synthesized copper oxide nanoparticles on metabolism and antioxidant activity to the crop plants Solanum lycopersicum and Brassica oleracea var. botrytis. J. Biotechnol. 2017, 262, 11-27. [CrossRef] [PubMed]

192. Sulaiman, G.M.; Tawfeeq, A.T.; Jaaffer, M.D. Biogenic synthesis of copper oxide nanoparticles using olea europaea leaf extract and evaluation of their toxicity activities: An in vivo and in vitro study. Biotechnol. Prog. 2018, 34, 218-230. [CrossRef] [PubMed]

193. Ahn, S.; Singh, P.; Jang, M.; Kim, Y.-J.; Castro-Aceituno, V.; Simu, S.Y.; Kim, Y.J.; Yang, D.-C. Gold nanoflowers synthesized using Acanthopanacis cortex extract inhibit inflammatory mediators in LPS-induced RAW264.7 macrophages via NF-кB and AP-1 pathways. Colloids Surf. B Biointerfaces 2018, 162, 398-404. [CrossRef] [PubMed]

194. Ateeq, M.; Shah, M.R.; Ali, H.; Kabir, N.; Khan, A.; Nadeem, S. Hepatoprotective and urease inhibitory activities of garlic conjugated gold nanoparticles. New J. Chem. 2015, 39, 5003-5007. [CrossRef]

195. Aswathy Aromal, S.; Philip, D. Green synthesis of gold nanoparticles using Trigonella foenum-graecum and its size-dependent catalytic activity. Spectrochim. Acta A Mol. Biomol. Spectrosc. 2012, 97, 1-5. [CrossRef] [PubMed]

196. Devipriya, D.; Roopan, S.M. Cissus quadrangularis mediated ecofriendly synthesis of copper oxide nanoparticles and its antifungal studies against Aspergillus niger, Aspergillus flavus. Mater. Sci. Eng. C Mater. Biol. Appl. 2017, 80, 38-44. [CrossRef] [PubMed]

197. Gnanavel, V.; Palanichamy, V.; Roopan, S.M. Biosynthesis and characterization of copper oxide nanoparticles and its anticancer activity on human colon cancer cell lines (HCT-116). J. Photochem. Photobiol. B 2017, 171, 133-138. [CrossRef] [PubMed]

198. Şahin, B.; Aygün, A.; Gündüz, H.; Şahin, K.; Demir, E.; Akocak, S.; Şen, F. Cytotoxic effects of platinum nanoparticles obtained from pomegranate extract by the green synthesis method on the MCF-7 cell line. Colloids Surf. B Biointerfaces 2018, 163, 119-124. [CrossRef] [PubMed]

199. Jayaseelan, C.; Gandhi, P.R.; Rajasree, S.R.R.; Suman, T.Y.; Mary, R.R. Toxicity studies of nanofabricated palladium against filariasis and malaria vectors. Environ. Sci. Pollut. Res. Int. 2018, 25, 324-332. [CrossRef] [PubMed]

200. Li, Y.; Wang, H.; Zhang, R.; Zhang, G.; Yang, Y.; Liu, Z. Biofabrication of polyphenols coated Nano palladium and its in-vitro cytotoxicity against human leukemia cell lines (K562). J. Photochem. Photobiol. B 2017, 175, 173-177. [CrossRef] [PubMed]

201. Mahendra, C.; Murali, M.; Manasa, G.; Ponnamma, P.; Abhilash, M.R.; Lakshmeesha, T.R.; Satish, A.; Amruthesh, K.N.; Sudarshana, M.S. Antibacterial and antimitotic potential of bio-fabricated zinc oxide nanoparticles of Cochlospermum religiosum (L.). Microb. Pathog. 2017, 110, 620-629. [CrossRef] [PubMed]

202. Gandhi, P.R.; Jayaseelan, C.; Mary, R.R.; Mathivanan, D.; Suseem, S.R. Acaricidal, pediculicidal and larvicidal activity of synthesized $\mathrm{ZnO}$ nanoparticles using Momordica charantia leaf extract against blood feeding parasites. Exp. Parasitol. 2017, 181, 47-56. [CrossRef] [PubMed]

203. Ishwarya, R.; Vaseeharan, B.; Kalyani, S.; Banumathi, B.; Govindarajan, M.; Alharbi, N.S.; Kadaikunnan, S.; Al-anbr, M.N.; Khaled, J.M.; Benelli, G. Facile green synthesis of zinc oxide nanoparticles using Ulva lactuca seaweed extract and evaluation of their photocatalytic, antibiofilm and insecticidal activity. J. Photochem. Photobiol. B Biol. 2018, 178, 249-258. [CrossRef] [PubMed] 
204. Angel Ezhilarasi, A.; Judith Vijaya, J.; Kaviyarasu, K.; John Kennedy, L.; Ramalingam, R.J.; Al-Lohedan, H.A. Green synthesis of $\mathrm{NiO}$ nanoparticles using Aegle marmelos leaf extract for the evaluation of in-vitro cytotoxicity, antibacterial and photocatalytic properties. J. Photochem. Photobiol. B 2018, 180, 39-50. [CrossRef] [PubMed]

205. Chen, G.; Xu, Y. Biosynthesis of cerium oxide nanoparticles and their effect on lipopolysaccharide (LPS) induced sepsis mortality and associated hepatic dysfunction in male Sprague Dawley rats. Mater. Sci. Eng. C Mater. Biol. Appl. 2018, 83, 148-153. [CrossRef] [PubMed]

206. Thandapani, K.; Kathiravan, M.; Namasivayam, E.; Padiksan, I.A.; Natesan, G.; Tiwari, M.; Giovanni, B.; Perumal, V. Enhanced larvicidal, antibacterial, and photocatalytic efficacy of $\mathrm{TiO}_{2}$ nanohybrids green synthesized using the aqueous leaf extract of Parthenium hysterophorus. Environ. Sci. Pollut. Res. Int. 2017, 23, 10328-10339. [CrossRef] [PubMed]

207. Khatami, M.; Alijani, H.; Sharifi, I.; Sharifi, F.; Pourseyedi, S.; Kharazi, S.; Lima Nobre, M.A.; Khatami, M. Leishmanicidal activity of biogenic $\mathrm{Fe}_{3} \mathrm{O}_{4}$ nanoparticles. Sci. Pharm. 2017, 85, 36. [CrossRef] [PubMed]

208. Sisubalan, N.; Ramkumar, V.S.; Pugazhendhi, A.; Karthikeyan, C.; Indira, K.; Gopinath, K.; Hameed, A.S.H.; Basha, M.H.G. ROS-mediated cytotoxic activity of $\mathrm{ZnO}$ and $\mathrm{CeO}_{2}$ nanoparticles synthesized using the Rubia cordifolia L. leaf extract on MG-63 human osteosarcoma cell lines. Environ. Sci. Pollut. Res. Int. 2017, 29, 1-11. [CrossRef] [PubMed]

209. Sowndarya, P.; Ramkumar, G.; Shivakumar, M.S. Green synthesis of selenium nanoparticles conjugated Clausena dentata plant leaf extract and their insecticidal potential against mosquito vectors. Artif. Cells Nanomed. Biotechnol. 2017, 45, 1490-1495. [CrossRef] [PubMed]

210. Defaei, M.; Taheri-Kafrani, A.; Miroliaei, M.; Yaghmaei, P. Improvement of stability and reusability of $\alpha$-amylase immobilized on naringin functionalized magnetic nanoparticles: A robust nanobiocatalyst. Int. J. Biol. Macromol. 2018, 113, 354-360. [CrossRef] [PubMed]

211. Das, P.; Barua, S.; Sarkar, S.; Karak, N.; Bhattacharyya, P.; Raza, N.; Kim, K.-H.; Bhattacharya, S.S. Plant extract-mediated green silver nanoparticles: Efficacy as soil conditioner and plant growth promoter. J. Hazard. Mater. 2018, 346, 62-72. [CrossRef] [PubMed]

212. Dayakar, T.; Rao, K.V.; Bikshalu, K.; Rajendar, V.; Park, S.H. Novel synthesis and characterization of pristine $\mathrm{Cu}$ nanoparticles for the non-enzymatic glucose biosensor. J. Mater. Sci. Mater. Med. 2017, 28, 109. [CrossRef] [PubMed]

213. Kurepa, J.; Nakabayashi, R.; Paunesku, T.; Suzuki, M.; Saito, K.; Woloschak, G.E.; Smalle, J.A. Direct isolation of flavonoids from plants using ultra-small anatase $\mathrm{TiO}_{2}$ nanoparticles. Plant J. 2014, 77, 443-453. [CrossRef] [PubMed]

214. Zhao, B.; Cao, X.; De La Torre-Roche, R.; Tan, C.; Yang, T.; White, J.C.; Xiao, H.; Xing, B.; He, L. A green, facile, and rapid method for microextraction and Raman detection of titanium dioxide nanoparticles from milk powder. RSC Adv. 2017, 7, 21380-21388. [CrossRef]

215. Xiao, D.; Zhang, C.; Yuan, D.; He, J.; Wu, J.; Zhang, K.; Lin, R.; He, H. Magnetic solid-phase extraction based on $\mathrm{Fe}_{3} \mathrm{O}_{4}$ nanoparticle retrieval of chitosan for the determination of flavonoids in biological samples coupled with high performance liquid chromatography. RSC Adv. 2014, 4, 64843-64854. [CrossRef]

216. Cao, X.; Ma, C.; Gao, Z.; Zheng, J.; He, L.; McClements, D.J.; Xiao, H. Characterization of the interactions between titanium dioxide nanoparticles and polymethoxyflavones using surface-enhanced Raman spectroscopy. J. Agric. Food Chem. 2016, 64, 9436-9441. [CrossRef] [PubMed]

217. Khan, M.A.; Wallace, W.T.; Islam, S.Z.; Nagpure, S.; Strzalka, J.; Littleton, J.M.; Rankin, S.E.; Knutson, B.L. Adsorption and recovery of polyphenolic flavonoids using $\mathrm{TiO}_{2}$-functionalized mesoporous silica nanoparticles. ACS Appl. Mater. Interfaces 2017, 9, 32114-32125. [CrossRef] [PubMed]

218. Schlipf, D.M.; Jones, C.A.; Armbruster, M.E.; Rushing, E.S.; Wooten, K.C.; Rankin, S.E.; Knutson, B.L. Flavonoid adsorption and stability on titania-functionalized silica nanoparticles. Colloids Surf. A Physicochem. Eng. Asp. 2015, 478, 15-21. [CrossRef]

219. Lee, D.; Ko, W.-K.; Hwang, D.-S.; Heo, D.N.; Lee, S.J.; Heo, M.; Lee, K.-S.; Ahn, J.-Y.; Jo, J.; Kwon, I.K. Use of baicalin-conjugated gold nanoparticles for apoptotic induction of breast cancer cells. Nanoscale Res. Lett. 2016, 11, 381. [CrossRef] [PubMed] 
220. Singh, B.; Rani, M.; Singh, J.; Moudgil, L.; Sharma, P.; Kumar, S.; Saini, G.S.S.; Tripathi, S.K.; Singh, G.; Kaura, A. Identifying the preferred interaction mode of naringin with gold nanoparticles through experimental, DFT and TDDFT techniques: Insights into their sensing and biological applications. RSC Adv. 2016, 6, 79470-79484. [CrossRef]

221. Pal, R.; Panigrahi, S.; Bhattacharyya, D.; Chakraborti, A.S. Characterization of citrate capped gold nanoparticle-quercetin complex: Experimental and quantum chemical approach. J. Mol. Struct. 2013, 1046, 153-163. [CrossRef]

222. Krishnan, G.; Subramaniyan, J.; Chengalvarayan Subramani, P.; Muralidharan, B.; Thiruvengadam, D. Hesperetin conjugated PEGylated gold nanoparticles exploring the potential role in anti-inflammation and anti-proliferation during diethylnitrosamine-induced hepatocarcinogenesis in rats. Asian J. Pharm. Sci. 2017, 12, 442-455. [CrossRef]

223. Pak, P.J.; Go, E.B.; Hwang, M.H.; Lee, D.G.; Cho, M.J.; Joo, Y.H.; Chung, N. Evaluation of the cytotoxicity of gold nanoparticle-quercetin complex and its potential as a drug delivery vesicle. J. Appl. Biol. Chem. 2016, 59, 145-147. [CrossRef]

224. Rajesh Kumar, S.; Priyatharshni, S.; Babu, V.N.; Mangalaraj, D.; Viswanathan, C.; Kannan, S.; Ponpandian, N. Quercetin conjugated superparamagnetic magnetite nanoparticles for in-vitro analysis of breast cancer cell lines for chemotherapy applications. J. Colloid Interface Sci. 2014, 436, 234-242. [CrossRef] [PubMed]

225. Shah, M.; Fawcett, D.; Sharma, S.; Tripathy, S.K.; Poinern, G.E.J. Green synthesis of metallic nanoparticles via biological entities. Materials 2015, 8, 7278-7308. [CrossRef]

226. Shaik, M.; Ali, Z.; Khan, M.; Kuniyil, M.; Assal, M.; Alkhathlan, H.; Al-Warthan, A.; Siddiqui, M.; Khan, M.; Adil, S. Green synthesis and characterization of palladium nanoparticles using Origanum vulgare L. rxtract and their catalytic activity. Molecules 2017, 22, 165. [CrossRef] [PubMed]

227. Rajendran, S.P.; Sengodan, K. Synthesis and characterization of zinc oxide and iron oxide nanoparticles using Sesbania grandiflora leaf extract as reducing agent. J. Nanosci. 2017, 2017, 7. [CrossRef]

(C) 2018 by the authors. Licensee MDPI, Basel, Switzerland. This article is an open access article distributed under the terms and conditions of the Creative Commons Attribution (CC BY) license (http:/ / creativecommons.org/licenses/by/4.0/). 